Technological University Dublin

DUBLIN

ARROW@TU Dublin

Articles

Crest: Centre for Research in Engineering

Surface Technology

2016-6

\title{
Biodegradable Magnesium Alloys for Orthopaedic Applications: A Review on Corrosion, Biocompatibility and Surface Modifications.
}

\author{
Sankalp Agarwal \\ Technological University Dublin, sankalp.agarwal@mydit.ie \\ James Curtin \\ Technological University Dublin, james.curtin@tudublin.ie \\ Brendan Duffy \\ Technological University Dublin, brendan.duffy@tudublin.ie
}

See next page for additional authors

Follow this and additional works at: https://arrow.tudublin.ie/cenresart

Part of the Other Medical Sciences Commons, and the Polymer Science Commons

\section{Recommended Citation}

Agarwal, S., Curtin, J., Duffy, B., \& Jaiswal, S. (2016). Biodegradable Magnesium Alloys for Orthopaedic Applications: A Review on Corrosion, Biocompatibility and Surface Modifications. Materials Science and Engineering: C. (doi: 10.1016/j.msec.2016.06.020)

This Article is brought to you for free and open access by the Crest: Centre for Research in Engineering Surface Technology at ARROW@TU Dublin. It has been accepted for inclusion in Articles by an authorized administrator of ARROW@TU Dublin. For more information, please contact arrow.admin@tudublin.ie, aisling.coyne@tudublin.ie,gerard.connolly@tudublin.ie.

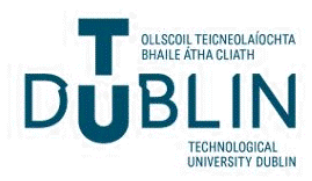




\section{Authors}

Sankalp Agarwal, James Curtin, Brendan Duffy, and Swarna Jaiswal 


\section{Accepted Manuscript}

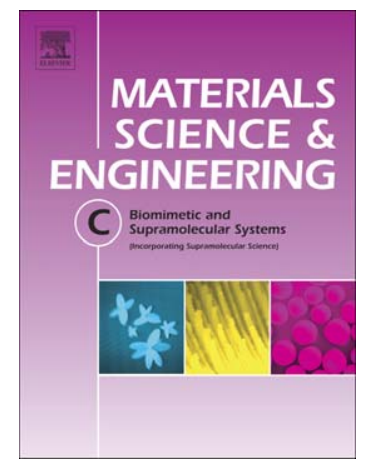

Biodegradable Magnesium Alloys for Orthopaedic Applications: A Review on Corrosion, Biocompatibility and Surface Modifications

Sankalp Agarwal, James Curtin, Brendan Duffy, Swarna Jaiswal

PII: $\quad$ S0928-4931(16)30590-2

DOI: $\quad$ doi: $10.1016 /$ j.msec.2016.06.020

Reference: $\quad$ MSC 6634

To appear in: $\quad$ Materials Science \& Engineering $C$

Received date: 21 October 2015

Revised date: $\quad 17$ May 2016

Accepted date: 7 June 2016

Please cite this article as: Sankalp Agarwal, James Curtin, Brendan Duffy, Swarna Jaiswal, Biodegradable Magnesium Alloys for Orthopaedic Applications: A Review on Corrosion, Biocompatibility and Surface Modifications, Materials Science \& Engineering C (2016), doi: 10.1016/j.msec.2016.06.020

This is a PDF file of an unedited manuscript that has been accepted for publication. As a service to our customers we are providing this early version of the manuscript. The manuscript will undergo copyediting, typesetting, and review of the resulting proof before it is published in its final form. Please note that during the production process errors may be discovered which could affect the content, and all legal disclaimers that apply to the journal pertain. 
Biodegradable Magnesium Alloys for Orthopaedic Applications: A Review on Corrosion, Biocompatibility and Surface Modifications

Sankalp Agarwal ${ }^{1,2}$, James Curtin ${ }^{2}$, Brendan Duffy $^{1}$, Swarna Jaiswal ${ }^{1}$ *

${ }^{1}$ Centre for Research in Engineering and Surface Technology, FOCAS Institute, Dublin Institute of Technology, Ireland

${ }^{2}$ School of Food Science and Environmental Health, Cathal Brugha Street, Dublin Institute of Technology, Ireland

Corresponding author: Dr. Swarna Jaiswal

Email Id: swarna.jaiswal@dit.ie 


\section{$\underline{\text { Abstract }}$}

Magnesium (Mg) and its alloys have been extensively explored as potential biodegradable implant materials for orthopaedic applications (e.g. Fracture fixation). However, the rapid corrosion of $\mathrm{Mg}$ based alloys in physiological conditions has delayed their introduction for therapeutic applications to date. The present review focuses on corrosion, biocompatibility and surface modifications of biodegradable Mg alloys for orthopaedic applications. Initially, the corrosion behaviour of $\mathrm{Mg}$ alloys and the effect of alloying elements on corrosion and biocompatibility is discussed. Furthermore, the influence of polymeric deposit coatings, namely sol-gel, synthetic aliphatic polyesters and natural polymers on corrosion and biological performance of $\mathrm{Mg}$ and its alloy for orthopaedic applications are presented. It was found that inclusion of alloying elements such as $\mathrm{Al}, \mathrm{Mn}, \mathrm{Ca}, \mathrm{Zn}$ and rare earth elements provides improved corrosion resistance to Mg alloys. It has been also observed that sol-gel and synthetic aliphatic polyesters based coatings exhibit improved corrosion resistance as compared to natural polymers, which has higher biocompatibility due to their biomimetic nature. It is concluded that, surface modification is a promising approach to improve the performance of $\mathrm{Mg}$-based biomaterials for orthopaedic applications. 


\section{Introduction}

Metallic orthopaedic implants have been used for the replacement and/or regeneration of damaged hard tissues [1]. Metallic implants are preferred for their high mechanical strength and toughness which make them superior to polymer and polymer-ceramic composites [2]. Orthopaedic metallic implants can be broadly classified into permanent (e.g knee or hip prostheses) and temporary biodegradable implants (e.g. Screws, pins, etc.) [2]. Metals such as stainless steel, titanium and cobalt-chromium alloys have been employed as permanent implants [3, 4]. However, there are some problems associated with the use of permanent metallic implants [5-7]. The first such problem includes incompatibility of mechanical properties of metallic alloys and natural bone; for example, metal alloys have greater elastic modulus to that of bone $[8,9]$. Under in vivo conditions, the mechanical mismatch between bone and implants leads to clinical phenomena called stress shielding [10, 11]. In stress shielding, the implant carries much of the bulk load and the surrounding bone tissue experiences a reduced load stress. This triggers the resorption of surrounding bone tissue [11]. To address this problem, permanent metallic alloys such as Co-Cr-Mo and Ti-6Al-4V have been manufactured into porous forms to reduce the modulus mismatch with natural bone [12]. A number of techniques are available to produce a porous metallic structure (fully porous metals or surface treatments) such as sintered metal powders, gas injection to metal melt, plasma spraying, use of foaming agents etc. [12]. However, development of porous metallic implants suffers from limitations such as brittleness, impurity of phases and limited control over the size, shape and distribution of porosity [13]. This limiting their orthopaedic applications. The second problem associated with permanent implants is mechanical wear and corrosion associated with the long term implantation in the body. This results in the release of toxic metal ions (chromium, nickel, cobalt etc.) in the body which can trigger the undesirable immune responses, thereby reducing the biocompatibility of metallic implants. 
[14]. Such drawbacks have compelled researchers and clinicians to look at biodegradable implants, which once used, only remain for an appropriate time to fix the damage.

Biodegradable metals have several advantages when used in orthopaedic fracture fixation (e.g. Screws, pins, etc.) [8]. The mechanical properties of $\mathrm{Mg}$ and its alloys such as Young's modulus of elasticity $(\mathrm{E}=41-45 \mathrm{GPa})$ and density $\left(1.74-1.84 \mathrm{~g} / \mathrm{cm}^{3}\right)$ are known to be similar that of bone $\left(\mathrm{E}=15-25 \mathrm{GPa}\right.$ and density= 1.8-2.1 $\left.\mathrm{g} / \mathrm{cm}^{3}\right)$. This is lower than other biodegradable materials such as Iron-Manganese (Fe-Mn) and Zinc (Zn) based alloys [2]. Furthermore, $\mathrm{Mg}$ ions are common metabolites in the body with a daily consumption range of 250-300 mg/day and are naturally stored in the bones [15]. Therefore, amongst biodegradable metals, the biocompatibility and the resemblance of mechanical properties of $\mathrm{Mg}$ and its alloys with bone makes it suitable for orthopaedic applications.

Ceramics which are inorganic non-metallic materials that have been employed in hard tissue engineering applications, are collectively known as Bioceramics [16]. Bioceramics possess desirable properties for biomedical applications such as (i) thermo-chemically stable, (ii) good wear resistant and (iii) are easily mouldable. Additionally, they are biocompatible, nontoxic and non-immunogenic $[17,18]$. However, bioceramics like hydroxyapatite (HAP) are brittle and possess low tensile strength when compared to $\mathrm{Mg}$ based alloys [18]. Ceramics have been used commercially in various applications like coatings for implants, maxillofacial reconstruction and drug delivery devices [19-21].

Polymeric materials have been employed for tissue engineering applications due to their ductility, biocompatibility and biodegradable nature. Polymers are composed of small repeating monomers which give the polymer its characteristic properties. The degree of cross linking of monomers determines the physiochemical nature of polymers [24]. In general, polymeric materials are broadly classified into synthetic and natural polymers. 
Synthetic polymers such as aliphatic poly-ester (poly lactic acid, poly glycolic acid, poly co(lactic-co-glycolic acid)) can be synthesized in controlled conditions to regulate properties such as molecular weight and derivatization. These advantages of synthetic aliphatic polyesters enable their use in biomedical applications. Natural polymers such as collagen and protein based gels, hyaluronic based derivatives, polysaccharide chitosan and heparin based scaffolds have been successfully used in various tissue engineering applications [22]. Natural polymers share properties similar to materials in the body and thus may encourage expeditious tissue healing by directing cell adhesion and function. Both classes of polymer can be chemically modified to produce tuneable scaffold and biomedical implants with controlled degradation rates. [23]. Moreover, several reports showed that the by-products of biodegradable polymers are highly biocompatible [24]. These polymers can be engineered into various shapes and sizes, such as disk, rod, pellets, plates, films and fibres as required. Some applications include biodegradable sutures, bone grafting materials, pins, screw and load bearing orthopaedic devices [25]. Despite possessing many desirable properties, polymers have low mechanical strength when compared to bioceramics and metal implants, thereby hindering their applications in hard tissue engineering. Therefore polymers have been largely employed in soft tissue engineering and low-load bearing medical devices [25]. Comparatively, $\mathrm{Mg}$ and its alloys have advantages over polymers due mechanical strength similar to bone.

From the above discussion, it can be observed that $\mathrm{Mg}$ based alloys have mechanical properties (density, yield strength, tensile strength, elongation to break and elastic modulus) similar to that of natural bone as compared to other biodegradable alloys, permanent implants, ceramics and polymers as showed in Table 1. Despite many advantages, the major limitation of $\mathrm{Mg}$ based alloys as biomedical materials is their high corrosion rate [26]. Corrosion results in the formation of $\mathrm{H}_{2}$ gas; which, if rapidly absorbed can lead to balloon 
effect in vivo [27]. Additionally, shift in alkaline $\mathrm{pH}$ in the region surrounding the corroding surface is also a concern for biomedical applications [28].

There are some strategies to improve the corrosion behaviour and biocompatibility:

a) Optimising the composition and microstructure, including grain size, crystalline structure phase and texture of the base metal through the development of manufacture process/methods.

b) To improve the corrosion behaviour and biocompatibility of $\mathrm{Mg}$ based implants through protective polymer deposit coatings on $\mathrm{Mg}$ and its alloys.

\section{Corrosion behaviour of $\mathrm{Mg}$ and its alloys}

The usual degradation of biomedical metals is through the corrosion process. Generally, the corrosion process involves electrochemical reactions to produce oxides, hydroxides and $\mathrm{H}_{2}$ gas species. In physiological conditions, the corrosion reactions of biodegradable metals including Mg and its alloys, involve the following anodic dissolution of metals and cathodic reduction reactions [8].

$$
\begin{gathered}
\mathrm{M} \rightarrow \mathrm{M}^{\mathrm{n}+}+\mathrm{ne}^{-} \text {(anodic reaction) } \ldots \ldots \ldots \ldots \ldots \ldots \ldots \ldots . \ldots \ldots \mathrm{Eq}-1 \\
2 \mathrm{H}_{2} \mathrm{O}+2 \mathrm{e}^{-} \rightarrow \mathrm{H}_{2}+2 \mathrm{OH}^{-} \text {(cathodic reaction) } \ldots \ldots \ldots \ldots \text { Eq-2 } \\
\mathrm{M}^{\mathrm{n}+}+\mathrm{nOH}^{-} \rightarrow \mathrm{M}(\mathrm{OH})_{n} \text { (overall product formation) } \ldots . . . \text { Eq-3 }
\end{gathered}
$$

In general, immediately after contact with moisture/ body fluids, $\mathrm{Mg}$ is oxidised to form cations following an anodic reaction (Eq-1). The generated electrons are consumed for reduction of water corresponding to cathodic reactions (Eq-2). These reactions occur randomly over an entire surface, where galvanic couples form due to differences in electrochemical potential between the metal matrix and intermetallic phases or with organic molecules adsorbed on the surface that lead to the dissolution of biodegradable $\mathrm{Mg}$ and its 
alloys [29]. Furthermore, physiological conditions are highly corrosive environment to $\mathrm{Mg}$ and its alloys such as dissolved oxygen, proteins and electrolyte ions (chloride and hydroxide ions) [30]. In these environments, pure $\mathrm{Mg}$ is susceptible to corrosion due to its high electrochemical potential, which results into the migration of ions from the metal surface to the surrounding fluid. These electrochemical reactions result in the formation of hydroxide layer $\left(\mathrm{M}(\mathrm{OH})_{\mathrm{n}}\right)$ on the surface of $\mathrm{Mg}$ and its alloys (Eq-3). When this metal oxide covers over the entire surface, it acts as a passive layer or kinetic barrier which prevents the further migration of ions or chemical reactions across the metal surface [30]. However, this layer is slightly soluble and susceptible to breakdown, particularly in the presence of chloride ions, that subsequently lead to the pitting corrosion (Eqn-4) [31].

$$
\mathrm{Mg}(\mathrm{OH})_{2}+2 \mathrm{Cl}^{-} \rightarrow \mathrm{MgCl}_{2}+2 \mathrm{OH}^{-} \ldots \ldots \ldots . . . \mathrm{Eq}-4
$$

Additionally, the corrosion of $\mathrm{Mg}$ and its alloys produce $\mathrm{H}_{2}$ gas. Initially, the rapid formation of $\mathrm{H}_{2}$ gas bubble subcutaneously occurs due to the enriched chloride environment, which can disappear after the initial weeks following surgery [27]. Song et al., postulated that hydrogen release rate of $0.01 \mathrm{ml} . \mathrm{cm}^{-2}$. day ${ }^{-1}$ can be tolerated by the body and does not pose a serious threat [32]. The corrosion in body fluids is influenced by various factors such as $\mathrm{pH}$, concentration and types of ions, protein adsorption on orthopaedic implant and influence of the biochemical activities of surrounding tissues [33-35]. The details of corrosion rates of $\mathrm{Mg}$ and its alloys under in vitro and in vivo conditions are given in Table 2. Typical forms of $\mathrm{Mg}$ corrosion encountered in physiological conditions are discussed in below sections:

\subsection{Galvanic corrosion}

Galvanic corrosion takes place when two dissimilar metals with different electrochemical potential come in contact with each other in the presence of an electrolyte [1]. The less noble metal acts as anode which corrodes rapidly producing by-products around the contact site 
[36]. Galvanic corrosion of $\mathrm{Mg}$ is the primary issue for orthopaedic applications. In the galvanic series, $\mathrm{Mg}$ is the most active metal, and always an active anode, if it made contact with other metals acting as higher potential (cathode) [36, 37]. Consequently, Mg alloy implant is preferentially corroded. The even galvanic attack can also result from the presence of impurities or intermetallic elements in the Mg matrix.

\subsection{Intergranular corrosion}

Intergranular corrosion (IGC) occurs at the grain boundaries due to the precipitation of secondary phases [37]. For conventional metals alloys, a secondary phase is more active than the interior of grain, thereby causing corrosion [28]. For example, some Aluminium ( $\mathrm{Al})$ and stainless steel alloys are susceptible to IGC [28]. However, it is argued that Mg alloys suffer this corrosion or not [37]. Song et al, explained that this type of intergranular corrosion does not occur in some $\mathrm{Mg}$ alloys [38]. This arises as the intergranular phase distributed along the grain boundary is more corrosion resistant than the $\mathrm{Mg}$ alloy matrix. Sometime, it has been observed that matrix adjacent to grain boundaries corroded severely for some $\mathrm{Mg}$ alloy with $\mathrm{Zr}$ as a grain refiner [28]. But, this is not real interganullar corrosion, as intergranular (secondary) phases are still intact. Ghali et al., demonstrated the IGC attack in AE81 alloy [39]. When the grain boundaries with low $\mathrm{Al}$ concentration corrode at a faster rate than that in $\mathrm{Al}$ rich regions, as can also be seen in other $\mathrm{Mg}$ - $\mathrm{Al}$ alloys. Another study showed the AZ80 $\mathrm{Mg}$ alloy IGC in 3.5\% $\mathrm{NaCl}$ for $1 \mathrm{hr}$ [37]. Where aging resulted in the decrease concentration of $\mathrm{Al}$ in $\alpha$-matrix in AZ80 which forms a poor protective oxide film on the surface and leading to breakdown [38]. As a result, the attack at $\alpha$-matrix commenced next to $\beta$-phase in aged AZ80. Therefore, it could be observed that concentration of $\mathrm{Al}$ along the grain boundaries affects the IGC of Mg alloys. 


\subsection{Pitting corrosion}

Pitting is a form of localized corrosion and associated with the breakdown of passivation layer in aggressive environment [36]. It is a serious form of corrosion when compared to other corrosion, since the surface pits are difficult to observe due to the presence of corrosion product [39]. The pits are highly corrosive, small and perforate the metal matrix. In general, after initial nucleation on the surface, impurities in the $\mathrm{Mg}$ alloy microstructure assist in further corrosion due to the galvanic differences in materials [40]. Moreover, the combination of chloride environment of body fluids and $\mathrm{Mg}$ ions from anodic dissolution species further accelerate the growth of the pit [40]. Once the pitting initiates, $\mathrm{Mg}$ component can be corroded in very short period of time, which in the case of orthopaedic applications would reduce the load bearing capacity of implants. Additionally, pitting increases the localised stress, which has the potential to form cracks [1]. The development of stress corrosion cracking (SCC) and metal fatigue cracks in the pits can lead to the implant failure under normal loading conditions.

\section{Factors affecting the corrosion resistance of $\mathrm{Mg}$ and its alloy}

\subsection{Buffer systems and Inorganic Ions}

In the physiological conditions, several buffers are involved to maintain the $\mathrm{pH}$ at neutral condition. The commonly used corrosion prototype medium is simulated body fluid (SBF) which consists of buffers such as $\mathrm{HEPES}$, Tris- $\mathrm{HCl}$ and $\mathrm{HCO}_{3}{ }^{-} / \mathrm{CO}_{2}$, which significantly affects the corrosion of $\mathrm{Mg}$ and its alloys [35]. The HEPES and Tris- $\mathrm{HCl}$ regulate the change in the $\mathrm{pH}$ by consuming the $\mathrm{OH}^{-}$ions, and affect the formation of corrosion product, consequently accelerate the dissolution of $\mathrm{Mg}$, as shown in Eqn-3. The $\mathrm{HCO}_{3}{ }^{-} / \mathrm{CO}_{2}$ imparts buffering system in the human body which not only utilise $\mathrm{OH}^{-}$ions, but also induce the 
precipitation of $\mathrm{MgCO}_{3}$ which contributes the protection against corrosion by developing the passivation layer on $\mathrm{Mg}$ [36].

Furthermore, the presence of inorganic ions in the body fluids influences the degradation of $\mathrm{Mg}$ and its alloys primarily by two manners: (a) the abundance of $\mathrm{Cl}^{-}$ions in physiological conditions, is aggressive in the removal of passivation layer from the surface and leading to pitting corrosion and (b) the presence of $\mathrm{HPO}_{4}^{2-} / \mathrm{PO}_{4}^{2-}, \mathrm{HCO}_{3}^{-} / \mathrm{CO}_{3}^{2-}$ anions and $\mathrm{Ca}^{2+}$ ions form calcium phosphate and carbonate salt precipitate which protect the erosion of passivation layer on $\mathrm{Mg}$ and its alloys, thereby preventing the emergence of pitting corrosion [46].

\subsection{Mechanical stress}

The attractive high strength of biodegradable $\mathrm{Mg}$ alloys as compared to biodegradable polymers, which makes them promising for load bearing orthopaedic applications. Potential biodegradable biomedical devices would be exposed to the complex stress environment in vivo, depending upon the implantation site, and would be expected to function under various mechanical stresses, including fluid shear stress, compression etc.

$\mathrm{Gu}$ et al., showed the increase in corrosion rate of as-extruded WE43 alloy and as-cast AZ91D under compression and cyclic loads [41]. The corrosion of these two alloys increased more than 10 times under applied loads when compared to unstressed equivalents [42]. Furthermore, the flow of electrolytes also influenced the corrosion rate of $\mathrm{Mg}$ based biomaterials. In case of $\mathrm{Mg}$ based biomaterials, the flow may produce fluid shear stress, which could help the deposition of corrosion product layer or, on the other hand, remove the locally generated $\mathrm{OH}^{-}$ions, thus affecting the corrosion behaviour [42, 43]. For instance, Leversque et al., reported that relatively low shear stress ( 0.88 and $4.4 \mathrm{~Pa})$ slow down the 
corrosion rate of AM60B alloy in the static Hanks' solution, whereas higher shear stress (8.8 $\mathrm{Pa}$ ) enhance the rate [151].

Furthermore, time dependent changes in the integrity of the mechanical properties of metal under prolonged mechanical stress is also a crucial factor [44]. Adequate mechanical strength of metal implant is required to assist the healing and is important for post-operative recovery. As the degradation of biomaterial proceeds; the degeneration of mechanical integrity is expected. The mechanical loads can accelerate this process because of both corrosion and stress that lead to stress corrosion cracking (SCC) and corrosion fatigue, thereby causing implant failure [45]. The cyclic stress develops the formation of microscopic cracks on the surface and also damages the protective passive layer, while the chloride environment in body fluids further significantly increases crack growth rate [46]. When the loading stress exceeds the threshold of SCC, the crack grows to a critical size, resulting in the fracture of the metallic implant. This infers that the environment can significantly reduce the fatigue limit of $\mathrm{Mg}$ alloys over an implantation period, producing considerable shorter failure times of implants.

\section{Effects of alloying element on mechanical and corrosion properties}

The Mg based biodegradable substrates can be divided into four major groups: (a) pure Mg, (b) Al containing alloys (AZ91, AZ31, LAE422, AM60 etc.) (c) Rare earth elements (AE21, WE43 etc.), and (d) Al free alloys (WE43, MgCa 0.8, MgZn6 etc.). These alloying elements improves the mechanical and physical properties of $\mathrm{Mg}$ alloys for orthopaedic applications by: (a) optimising grain size, (b) improve corrosion resistance, (c) providing mechanical strength by the formation of intermetallic states and (d) eases the manufacture process of $\mathrm{Mg}$ alloys [1]. The composition of some Mg based alloys are given in Table 3. In this section, the 
effects of some important alloying elements on the mechanical properties and corrosion behaviours of $\mathrm{Mg}$ alloys are also discussed.

As an alloying element, $\mathrm{Al}$ is commonly used for modifying the mechanical and corrosion properties of $\mathrm{Mg}$ alloys [47]. Addition of $\mathrm{Al}(1-5 \%)$ lead to the reduction of grain size, while content greater than 5\% does not affect the grain size [48]. Generally, Al dissolves partly in $\mathrm{Mg}$ solid solutions and precipitate as $\mathrm{Mg}_{17} \mathrm{Al}_{12}$ secondary phases along the grain boundaries [47]. The as-cast $\mathrm{Mg}-\mathrm{Al}$ alloys show $\alpha-\mathrm{Mg}$ matrix and $\beta$-phases mainly consisting of $\mathrm{Mg}_{17} \mathrm{Al}_{12}$ phases [49]. In the presence of electrolytes, these phases show different electrode potentials. The $\mathrm{Mg}_{17} \mathrm{Al}_{12}$ phase exhibits a passive behaviour, acting as a cathode with respect to the $\alpha$-phase of $\mathrm{Mg}$ matrix, thereby accelerating the corrosion of the alloy [49]. However, the inert nature of $\mathrm{Mg}_{17} \mathrm{Al}_{12}$ phase can itself act as a corrosion barrier, thereby reducing the corrosion in AZ91D alloys [50]. Song et al., suggested that if $\beta$-phase volume fraction is higher and distributed along the grain boundary, it might act as a corrosion barrier surrounding the $\alpha-\mathrm{Mg}$ matrix thereby reducing the corrosion rates [51].

Calcium (Ca) acts as a grain refining agent in Mg alloys, stabilising the grain size at levels up to $0.5 \% \mathrm{Ca}$ content and decreases slightly with further addition [52]. Li et al, studied the MgCa binary alloys with increasing concentration of Ca from $0.5 \%$ to $20 \%$ [52]. The increase in $\mathrm{Ca}$ addition resulted in a high content of $\mathrm{Mg}_{2} \mathrm{Ca}$ secondary phase distribution towards grain boundaries. The $\mathrm{Mg}_{2} \mathrm{Ca}$ secondary phase is brittle reducing the ductility of $\mathrm{Mg}-\mathrm{Ca}$ alloys with increase in $\mathrm{Ca}$ concentration. This also influences the corrosion properties of $\mathrm{Mg}$ alloys. $\mathrm{A}$ high volume fraction of the $\mathrm{Mg}_{2} \mathrm{Ca}$ secondary phase reduces the corrosion resistance of $\mathrm{Mg}$ Ca alloys due to the formation of micro-galvanic cells [53]. Therefore, it can be observed that the excessive $\mathrm{Ca}$ concentration accelerates the corrosion of $\mathrm{Mg}-\mathrm{Ca}$ alloys, and the optimum Ca concentration should be $\leq 1 \%[52]$. 
Manganese (Mn) is commonly used as a secondary element in Mg alloys. It has been claimed that the grain size decreases with increasing Mn content in Mg-Al-Mn alloy, but at levels above $0.4 \%$ this effect ceases $[49,15]$. It has also been reported that Mn addition can improve the tensile strength and fatigue life of extruded AZ31, AZ61 and AZ21 alloys [49]. Song et al, suggested that $\mathrm{Mn}$ improve the corrosion resistance in $\mathrm{Al}$ containing $\mathrm{Mg}$ alloys by transforming the Iron (Fe) and other impurities into harmless intermetallic compounds [51]. However, the excessive addition of $\mathrm{Mn}$ reduces the corrosion resistance of $\mathrm{Mg}$ - $\mathrm{Al}$ alloys due to the formation of a large amount of Mn-containing $\mathrm{Mg}$ - $\mathrm{Al}$ intermetallic phases which can be prone to galvanic effects.

Similarly to Mn, Zinc (Zn) has the ability to transform impurities such as Iron (Fe), Copper $(\mathrm{Cu})$ and Nickel $(\mathrm{Ni})$ into harmless intermetallic compounds, thereby reducing their corrosion enhancement effect [51]. It has been reported that the addition of $\mathrm{Zn}$ is associated with the grain refinement and formation of secondary phases, thus influencing the mechanical and corrosion properties of $\mathrm{Mg}$ alloys $[49,55]$. Yin et al. showed that the addition of $3 \% \mathrm{Zn}$ in $\mathrm{Mg}-\mathrm{Zn}-\mathrm{Mn}$ alloys forms $\mathrm{Mg}-\mathrm{Zn}$ secondary phases which precipitate out of the Mg-matrix, thus improving the strength through a dispersion strengthening mechanism [54]. Song et al. also studied the effect of $\mathrm{Zn}$ alloying on corrosion behaviour of Mg alloys [55]. It was found that micro-galvanic effects dominate the corrosion behaviour of $\mathrm{Mg}-\mathrm{Zn}$ alloys, thereby restricting $\mathrm{Zn}$ to levels less than 5\%. Above 5\% addition results in the formation of high volume fraction of $\mathrm{Mg}-\mathrm{Zn}$ secondary phases which act as cathodes, accelerating the corrosion of $\alpha-\mathrm{Mg}$ matrix around the $\mathrm{Mg}-\mathrm{Zn}$ phases in $\mathrm{Mg}$ alloys.

Lithium (Li) can alter the lattice structure from hexagonal close-packed (h.c.p.) to bodycentred-cubic (b.c.c.) crystal structure in Mg alloys [56]. Therefore, it can be employed to enhance the ductility and formability of $\mathrm{Mg}$ alloys [49]. $\mathrm{Li}$ is more reactive than $\mathrm{Mg}$ and has a pronounced effect on the corrosion behaviour of $\mathrm{Mg}$ alloys. Li content below $9 \%$ in pure 
$\mathrm{Mg}$ is beneficent to corrosion resistance, whereas excess addition of $\mathrm{Li}$ is detrimental to the corrosion resistance $[57,58]$.

Rare-earth elements (REEs) are a group of seventeen elements, including fifteen lanthanides, scandium (Sc) and yttrium (Y). They are normally added to $\mathrm{Mg}$ alloys as master alloys or hardeners and can improve the strength and corrosion resistance by both solid solution and precipitation hardening [56]. The REEs can be classified into two groups (i) High solubility group (yttrium (Y), gadolinium (Gd), terbium (Tb), dysprosium (Dy), holmium (Ho), erbium (Er), thulium (Tm), ytterbium (Yb), and lutetium(Lu)) and (ii) limited solubility group (neodymium $(\mathrm{Nd})$, lanthanum $(\mathrm{La})$, cerium $(\mathrm{Ce})$, praseodymium $(\mathrm{Pr})$, samarium $(\mathrm{Sm})$, europium (Eu)) [56]. For example, Y has a high solid-solution solubility in $\mathrm{Mg}$ and is often introduced along with other rare earth elements to improve creep and corrosion resistance [33].Moreover, most of REEs form intermetallic phases with $\mathrm{Mg}$ and $\mathrm{Al}$ which have a pronounced effect on the strength and corrosion of $\mathrm{Mg}$ alloys [59]. Several REE-doped $\mathrm{Mg}$ alloys such as WE43, Mg-5Gd, LAE442 and Mg-4Y have been investigated [33]. In WE43, main precipitated phases are $\mathrm{Mg}_{12} \mathrm{YNd}$ and $\mathrm{Mg}_{14} \mathrm{YNd}$ [60]. For $\mathrm{Mg}-\mathrm{Gd}$ alloy, $\mathrm{Mg}_{5} \mathrm{Gd}$ intermetallic phases can precipitate both in grains and at grain boundaries. In Mg-Al-REE systems, the REE tend to form intermetallic phases with $\mathrm{Al}$ as $\mathrm{Al}_{12} \mathrm{REE}$ and $\mathrm{Al}_{11} \mathrm{REE}_{3}$ improving strength and corrosion resistance [60]. Furthermore, the REE elements with limited solubility tend to form inter-metallic phases early during the solidification process [56]; for example, Ce aggregate at solid-liquid interfaces during solidification in Mg-Al-Ce alloys. During solidification, Al-Ce secondary phases form and segregate along the grain boundaries, effectively blocking the sliding of boundaries during deformation [49]. Al-Ce particles also influence the corrosion rate in $\mathrm{Mg}$-Al-Ce alloys. Higher content of $\mathrm{Ce}$ in alloys leads to $\mathrm{Al}_{11} \mathrm{Ce}_{3}$ particles forming a network surrounding the $\mathrm{Mg}$ matrix acting as a microgalvanic cathode and thus delaying the corrosion of the $\mathrm{Mg}$ alloys due to a very small 
potential difference [61]. Additionally, Al-Ce phase exhibits passivation in a wide range of $\mathrm{pH}$, which further retards the corrosion of Mg alloys [49].

The characteristic impurities in $\mathrm{Mg}$ alloys are copper $(\mathrm{Cu})$, nickel $(\mathrm{Ni})$, iron $(\mathrm{Fe})$ and beryllium (Be). Typically, $\mathrm{Cu}$ is limited to $100-300 \mathrm{ppm}$, Ni should not exceed 20-50 ppm and $\mathrm{Fe}$ and Be are limited to 35-50 ppm and 5 ppm respectively [56]. These impurities should be strictly controlled under toxic limits for biomedical applications.

\section{Pathophysiology and toxicology of alloying elements used for biodegradable $\mathrm{Mg}$ based orthopaedic implants}

The released metallic ions resulting from the corrosion of biodegradable $\mathrm{Mg}$ alloys may induce systemic toxicity to human, as well as localised toxicity to the peri-implant cells. Table 4 summarises the pathophysiology and toxicology of $\mathrm{Mg}$ and the common alloying elements. Generally, toxic element ions released in the body could be tolerated at very low concentration below its threshold level, while the excess release in the body will have adverse effects [62]. As $\mathrm{Mg}$ is the most abundant element present in the body, it shows very low toxicity, however in-depth biological studies are still required. Therefore, the amount of alloying element utilised for the manufacture of $\mathrm{Mg}$ based biomedical implants need to be optimised with respect to corrosion rates and the physiological environment at implant sites. It is essential that biomedical implants should be designed to control the localised release of metal ions below threshold levels, since the concentration of released metal ions into tissues influenced by various factors like (a) interfacial space between the metal and implants, (b) fluid flow shear stresses between the biomedical implant and bone, (c) variation in $\mathrm{pH}$ and (d) local blood supply [63].

The biological effects of released metal ions from biodegradable medical implants affect the cells of the surrounding tissue. Table 4 summarises the toxic dose at $50 \%$ cell viability 
(TD50) of bone related cells (MC3T3E1 and MG63 cell lines). From Table 4, the alloying elements are divided into mild, moderate and sever toxic elements [64]. The mild toxic elements include $\mathrm{Mg}, \mathrm{Ca}, \mathrm{Li}, \mathrm{Al}$ and $\mathrm{Zr}$. However, some reports showed that mild toxic element like $\mathrm{Al}(500 \mathrm{nM})$ at very low concentration induces bone related cells proliferation [65]. Moderate toxic element includes $\mathrm{Y}$, whereas $\mathrm{Zn}, \mathrm{Ni}, \mathrm{Cu}$ and $\mathrm{Mn}$ are severe toxic elements. Thus, moderate toxic or mild toxic elements should only be used to significantly improve the corrosion resistance to make the clinically feasible $\mathrm{Mg}$ based alloy orthopaedic implants $[64,65]$. Additionally, other strategies such as polymer deposit coatings on $\mathrm{Mg}$ based substrates have also been employed to prevent its rapid degradation, thereby facilitating the controlled exposure of these metal ions into the body.

\section{Effect of polymeric deposit coatings on Mg alloys degradation and biocompatibility}

In general, the healing process of bone consists of three phases; inflammatory, reparative and remodelling. In inflammatory phase, the immune system of the body responds against the foreign body, i.e. metallic implant fixed in the body [66]. In reparative phase, integration of the implant with new bone and regeneration of tissue takes place. Remodelling phase is one of the longest phases in the healing process. For regeneration of bone, this process takes a minimum 12 weeks, and unfortunately most of the $\mathrm{Mg}$ based orthopaedic implant can degrade within this period [8]. Therefore, there is a need to increase corrosion resistance of Mg based alloys.

A potential method for enhancing the corrosion resistance of $\mathrm{Mg}$ alloy without altering the bulk properties of material is through protective polymeric deposit coatings. Typically, the bulk properties of $\mathrm{Mg}$ regulate the mechanical integrity, but the surface properties play important roles in various physio-chemical processes like interaction of body fluids, adhesion of biomolecules and cells with biomedical implants, which initiate the corrosion process [8]. 
Therefore, the coating should be biocompatible, but also degrade at a slower rate than that of $\mathrm{Mg}$ and its alloys. Polymeric deposit coatings are attractive, since they possess good biocompatibility with the body and have a range of degradation rates. This section discusses the role of deposit coatings (sol-gel, synthetic aliphatic-polyesters and natural polymers) in improving the corrosion resistance and biocompatibility of $\mathrm{Mg}$ alloys.

\subsection{Sol-gel coatings}

The sol-gel process involves the creation of an oxide network through progressive reactions of the precursor solution in a liquid medium. Basically, there are two methods of sol-gel preparation (a) inorganic and (b) organic [67]. The inorganic method involves evolution of network formation through the gelation of suspended colloidal particles of size 1-1000 nm in continuous liquid phase [68]. The organic method generally involves the solution of monomeric metal or metalloid alkaloid precursor in alcohol or organic solvent [69]. In general, sol-gel formation occurs in four stages (a) hydrolysis, (b) condensation and polymerisation of monomers to form chains and particles, (c) particle growth and (d) agglomeration of the polymer structures followed by the network formation throughout in liquid medium which increases the viscosity to form a gel [70]. In fact, hydrolysis and condensation reaction starts simultaneously, once the hydrolysis reaction has been initiated [67]. These reactions yield by-product such as water and alcohol. These processes are influenced by initial reaction conditions such as, $\mathrm{pH}$, molar ratio of water to precursor solution, temperature and solvent composition [71].

According to available literature, silane based sol-gel coatings have been used widely as an anti-corrosive and biocompatible coatings on $\mathrm{Mg}$ alloy for orthopaedic applications. There are several reasons using silane as anti-corrosive coatings such as (a) hydrophobic Si-O-Si 
network (b) lower susceptibility to galvanic reactions with $\mathrm{Mg}$, (c) greater adhesive properties, (d) easily chemically modifiable and (e) less cytotoxic in nature [72].

Gaur et al., reported the in vitro investigation of biodegradable composite silane coatings of diethylphosphatoethyltriethoxysilane (DEPETES) and bis-[3-(triethoxysilyl)propyl] tetrasulfide (BTESPT) for corrosion resistance of $\mathrm{Mg}-6 \mathrm{Zn}-\mathrm{Ca}$ alloy in the simulated body fluid (SBF) [73]. Initially, the Mg alloy was pre-treated in alkaline conditions to generate a passivation layer, followed by coating with different volume ratios of DEPETES: BTESPT (1:1 to $1: 4)$ and curing at $120^{\circ} \mathrm{C}$ for $1 \mathrm{hr}$. The corrosion resistance was evaluated by EIS (Electrochemical Impedance Spectroscopy) and polarisation studies. Samples coated with DEPETES: BTESPT (1:4) showed a near six fold increase in corrosion resistance as compared to bare $\mathrm{Mg}$ alloy in SBF. The corrosion protection of composite coating was attributed to highly dense Si-O-Si network formation. Similarly, Khramov et al., demonstrated the corrosion resistant sol-gel coatings with hybrid inorganic-organic phosphonate silane on AZ31B Mg alloy [74]. These coatings were prepared by mixing of diethylphosphonato-ethyl-triethoxy-silane (PHS) and tetraethoxy-silane (TEOS) with various molar ratios (PHS: TEOS- 1:1 to 1:4), and evaluated for corrosion resistance in Harrison solution by using EIS and potentiodynamic polarisation studies. The sample coated with PHS: TEOS 1:4 showed greater corrosion resistance as compared to bare and TEOS coated AZ31B Mg alloy respectively. This enhancement in corrosion was attributed to the chemical reaction of phosphonate functionalities with the surface of the alloy, resulting in improved hydrolytically stable P-O-Mg bonds.

In addition to silane coatings, other metal based precursors sol-gel coatings have been used as a surface modification for preventing corrosion of $\mathrm{Mg}$ alloys. For example, Shi et al., showed that the titania coating on pure Mg implant was compatible with PEO (Plasma Electrolytic Oxidation) treated surface covers all the surface area (including pores) [75]. Furthermore, 
Lalk et al., developed biodegradable Mg sponges coated with bioactive glass using the solgel method [76]. This coating was predominantly composed of calcium phosphate and silica containing phosphate. The corrosion resistance was determined by soaking in DMEM medium (Dulbecco's Modified Eagle's Medium), and found to be stable for 3 days. However, enhanced corrosion resistance was not observed for a longer duration due to the development of defects in the coating. Additionally, osteoblast cells (MC3T3E1) showed good biocompatibility as compared to uncoated surface. Furthermore, Ishizaki et al., developed a corrosion resistant super hydrophobic surface on $\mathrm{Mg}$ alloys with cerium oxide film and fluroalkylsilane molecules (Figure 1) [77]. It was demonstrated that the super hydrophobic coating (advancing and receding contact angles are $153.2^{\circ}$ and $146.6^{\circ}$ respectively) enhanced the corrosion resistance with more than one fold as compared to bare $\mathrm{Mg}$ alloy in $5 \% \mathrm{w} / \mathrm{v}$ $\mathrm{NaCl}$.

\subsection{Synthetic aliphatic polyester coatings}

In general, biocompatible polymeric implants for orthopaedic applications have not been found suitable due to poor mechanical properties [1, 78]. Therefore, such polymers are generally deposited as anticorrosive coatings on orthopaedic implant. Usually, these polymeric materials enhance the corrosion resistance of $\mathrm{Mg}$ based metals by isolating the device from the fluidic and corrosive environment of the body [1, 24]. The biocompatible properties of polymers are critical because their presence at the interface of implant and body environment which could elicit the immunological response. Therefore, selecting the appropriate polymer coating is crucial in improving the corrosion resistance and biocompatibility of orthopaedic metals, including $\mathrm{Mg}$ and its alloys.

There are several advantages of polymers as they can be easily modified chemically, physically and mechanically, enabling their use in a wide range of biomedical applications 
[82-84]. Polymers applied as coatings on Mg based biomaterials for orthopaedic applications showed in Table 5, which enlist the degraded products and corrosion behaviour of polymer coatings.

Synthetic aliphatic polyesters such as poly lactic acid (PLA), poly-co-lactic-glycolic acid (PLGA), polycaprolactone (PCL), polyethyleneimine (PEI) and many other polymers have been used in various biomedical applications [79]. These polymeric materials are attractive coatings on $\mathrm{Mg}$ and its alloys to control the initial rate of degradation, as their degradation rate is based on their molecular weight [79]. In particular, lactic and glycolic acid based polymers such as PLA and PGA, have been studied extensively as corrosion resistant coatings for orthopaedic applications. Similarly, a significant work has been carried out in copolymers of lactide and glycolide i.e PLGA [80]. A co-polymer of 50\% lactide and glycolide degrades faster as compared to corresponding homo-polymer. PCL also degrades slower than PLA [81]. The polymeric deposit coatings on orthopaedic Mg devices can also enhance the mechanical strength, with nontoxic degradation products enabling osteoinductive and osteogenic environments [82-84]. However, many of the currently available polymers does not fulfil the requirement, and would require chemical modifications, if they are to be applied for such applications. This section discusses the corrosion resistance and biocompatibility of selected aliphatic polyester based polymers coating on $\mathrm{Mg}$ and its alloys.

\subsubsection{Poly lactic acid}

Biodegradable polymers such as poly lactic acid (PLA) have been explored extensively for biomedical application. PLA is highly biocompatible, semi crystalline and hydrophobic in nature [24]. It undergoes hydrolytic degradation and the by-products such as lactic acid is easily metabolised in the body without exhibiting any toxicity. However, the major drawback of the PLA as a load bearing implant for orthopaedic applications is that it possesses poor 
mechanical properties as compared to bone [1]. On the other hand, it can be used as an anticorrosion coating on $\mathrm{Mg}$ alloys to slow down the hydrolytic degradation rate and the evolution of $\mathrm{H}_{2}$ gas [85]. However, it is depended on the concentration of PLA and the application technique [86].

Chen et al., studied the corrosion resistance properties of PLA coated on pure Mg in SBF. They reported bulging in the coating due to underlying accumulation of $\mathrm{H}_{2}$ gas, leading to the rapid destruction of $\mathrm{Mg}$ substrate [87]. This effect was attributed to SBF penetration through defects in the coating which initiated corrosion. Interestingly, Alabbasi et al, proposed the inappropriate use of pure $\mathrm{Mg}$ as a substrate for dip coating with PLA [88]. They explained that pure $\mathrm{Mg}$ is highly vulnerable to corrosion in $\mathrm{SBF}$; and as consequence corrosion begins rapidly upon permeation of SBF through defects in the coating. Secondly, the dip coating resulted in non-uniform thick PLA coating with poor adhesion, thereby showing poor corrosion resistance. In order to show the utility of PLA in enhancing the corrosion resistance, Alabbasi et al., employed the spin coating technique for uniform coating of PLA on AZ91D Mg alloy. It has been shown that the corrosion resistance increases with concentration and uniformity in thickness of PLA coating on AZ91D Mg alloy. Therefore, it could be observed that selection appropriate coating techniques (dip coating, spin coating and spray coating) play an important role in studying the efficiency of polymer coating in preventing the corrosion of $\mathrm{Mg}$ and its alloys.

Zeng et al., reported the coating of PLA on MAO (micro-arc oxidation) treated Mg-1.21Li1.12Ca-1.0Y alloy [86]. The corrosion resistance was evaluated by EIS and polarisation studies. It was observed that the MAO/PLA composite imparts corrosion resistance to the alloy within the physiological $\mathrm{pH}$ range of 7.5- 7.8. The results indicated that PLA/MAO composite coating can become a promising biomedical coating. Similarly Shi et al., 
demonstrated the utility of PLA for improving the corrosion resistance of MAO treated AZ31 $\mathrm{Mg}$ alloy in SBF [85]. Here, layer by layer PLA coating was prepared in PLA-chloroform solution. The corrosion resistance of PLA coated MAO/AZ31 alloy was compared with MAO/AZ31 and both PLA and AZ31 alloy in SBF for $24 \mathrm{hrs}$. The PLA/MAO alloy was 100 and 38 times more corrosion resistant than untreated bare AZ31 and MAO treated equivalents respectively. This result was broadly attributed to mechanical interlocking of PLA coating with MAO treated alloy as compared to other samples.

Furthermore, porous calcium silicate (WT) has been considered as a potential bioactive material for bone tissue engineering. However, insufficient mechanical strength and high degradation rates have limited their biological applications. Wu et al., modify the porous calcium silicate with poly D,L-lactic acid (PDLLA) to improve the mechanical properties [89]. It was observed that PDLLA-modified WT (WTPL) scaffolds maintained a more uniform, continuous inner network, pore size, porosity and interconnectivity of the original materials when compared to WT sample alone. As a result of this combination, the compressive strength, modulus and percentage strain of the WTPL scaffold were increased significantly when compared to WT alone. Moreover, PDLLA modification also improved the spreading, adhesion and viability of human bone-derived cells. Hence, it could be proposed that the intrinsic properties of PLA can be exploited for potential application for bone tissue regeneration.

\subsubsection{Poly (lactic-co-glycolic) acid}

PLGA (Poly(lactic-co-glycolic)acid)) co-polymers are FDA approved for clinical applications, mainly due to their excellent biocompatibility [24]. They are hydrolytically and enzymatically (trypsin or lysozyme) degraded into glycolic and lactic acid which are easily assimilated by metabolic pathways [90]. The physical, mechanical and chemical properties of PLGA can be engineered by altering the ratio of the two-co-monomers. Several compositions 
of co-polymer of glycolic acid and lactic acid have been investigated. These co-polymers are usually two types (a) (l) LA/GA (b) (dl) LA/GA. The composition of (1) LA/GA ranges of 20 to $70 \%$ and of 0 to $70 \%$ for (dl) LA/GA are amorphous in nature [91]. Reed et al., showed that (1) LA/GA co-polymers are more resistant to hydrolysis [92]. The LA/GA (30/70) has the higher water absorption capacity and more susceptible to hydrolysis, while the LA/GA (50/50) co-polymer is most unstable with respect hydrolysis. These advantages of PLGA have been exploited for important applications such as corrosion protection and drug delivery.

Ostrowaski et al., reported on the corrosion and biocompatibility properties of the PLGA coating of varying thickness on AZ31and MgY4 alloy for orthopaedic applications [93]. In their study, two coatings of different thickness $1.6 \mu \mathrm{m}$ and $41.8 \mu \mathrm{m}$ were prepared on AZ31 alloy, whereas $1.6 \mu \mathrm{m}$ and $62.1 \mu \mathrm{m}$ thick coatings were deposited on MgY4 alloy. The corrosion resistance was measured using EIS and potential dynamic methods in SBF. It was observed that corrosion decreased with increased PLGA thickness. An improvement in corrosion resistance was observed for only 3 days, thereafter did not maintain a reduction in corrosion rate. The topographical analysis showed that the entrapped gas in the coating caused the detachment of coatings from the alloy surface. The biocompatibility studies showed enhanced adhesion and proliferation of osteoblast cells. Furthermore, a separate study was carried out using pre-treatment of AZ31 alloy and composition of PLGA. The alloy was pre-treated to form $\mathrm{Mg}(\mathrm{OH})_{2}$ layer and subjected to dip coating with PCL and PLGA with varying composition (75/25 and 50/50). The corrosion measurements showed that PCL offered the greatest resistance, followed by PLGA (50/50) and PLGA (75/25) when compared to an uncoated alloy for 1 week in culture medium. Additionally, these coatings were biocompatible with good adhesion, proliferation and differentiation of MC3T3E1 osteoblast cells and human mesenchyme stem cells. 
Furthermore, Chen et al., exploited the existing regular application of PLGA in drug delivery for enhancing the corrosion resistance of Mg alloys [94]. Instead of employing a drug loaded PLGA coating, an active PLGA coating was fabricated loaded with inhibitor benzotriazole (BTA) through an electrospray process, which is capable of inhibiting corrosion of $\mathrm{Mg}$ alloys. Principally, it has shown that rapid response of PLGA particle to both water and $\mathrm{pH}$ change, which lead to instant release of BTA to self-healing the protective functionality, and prevent further corrosion.

Li et al, studied the corrosion and cell adhesion efficacies of PLGA coating on Mg-6Zn alloy (Figure 2a and b) [95]. The Mg-6Zn alloy was coated with different concentrations of PLGA to enhance the corrosion resistance in $0.9 \% \mathrm{NaCl}$ solution. The corrosion resistance was evaluated by using EIS and potentiodynamic polarisation studies. A significant anticorrosive activity was observed with $2 \%$ PLGA, but not $4 \%$ PLGA. However, both substrates showed better corrosion resistance when compared to bare alloy by a factor over 100. The decrease in corrosion inhibition with higher concentration of PLGA was attributed to thick coating (76 $\mu \mathrm{m})$ and poor adhesion with Mg alloy. Furthermore, PLGA substrate showed good adhesion for MC3T3E1 osteoblast cells (Figure 2b). Hence, PLGA co-polymer properties can be exploited to prevent the corrosion of $\mathrm{Mg}$ based alloys for orthopaedic implants

\subsubsection{Poly caprolactone}

Poly caprolactone (PCL) is the most studied polymer in the family of polylactones [24]. The glass transition temperature is $-60^{\circ} \mathrm{C}$ and melting point is between $59{ }^{\circ} \mathrm{C}$ to $63{ }^{\circ} \mathrm{C}$. It degrades slower than PLA, and is useful for drug delivery as wells as anti-corrosive coatings. The homopolymer PCL has a degradation time about 24 to 36 months. The rate of hydrolysis can be altered by co-polymerising with other polymers like valerolactones, dl-lactide etc [24]. For example, co-polymers with epsilon caprolactone and dl-lactide have been synthesised to yield polymeric material with a higher degradation rate (e.g. biodegradable sutures). PCL is 
considered to be a nontoxic biodegradable material and suitable as a protective coating on $\mathrm{Mg}$ based alloy for orthopaedic applications.

Park et al., studied the varying thickness of PCL for controlled corrosion of $\mathrm{Mg}$ for orthopaedic applications [96]. Their report studied the layer by layer coating of PCL using dip coating with progressive increase in average thickness from 2.8 to $13 \mu \mathrm{m}$ on pure $\mathrm{Mg}$. The degradation rate was measured by evolution of hydrogen gas in Hanks' solution for 14 days. It was observed that the rate of degradation decreases with increases in coating thickness. However, the high absorption of water was observed in the early stages, damaging the coating by decreasing the adhesion of the film on pure $\mathrm{Mg}$. Furthermore, Li et al., combined the MAO treatment of pure Mg coatings of PCL polymer to improve its corrosion resistance [97]. A uniform PCL coating was prepared on $\mathrm{MAO} / \mathrm{Mg}$ and corrosion resistance measurements were evaluated using potentiodynamic polarisation and immersion test in Hanks' solution for 7 days. Results indicated the significant corrosion resistance of porous MAO/Mg/PCL (4-7 \%w/v) substrate when compared to an uncoated MAO/Mg sample. Thus, pre-treated Mg with PCL coating could be good alternative for orthopaedic. Similarly, Degner et al. demonstrated the corrosion resistance of PCL coated pure Mg in DMEM (corrosive medium) for one month at $37^{\circ} \mathrm{C}$ through electrochemical investigations [98]. It was shown that with increases in the concentration of PCL $(2.5$ to $7.5 \% \mathrm{w} / \mathrm{v})$ the corrosion resistance increases 10 folds. Hence, it can be observed that PCL could act as a potential protective coating to prevent the corrosion of $\mathrm{Mg}$ based alloys for orthopaedic applications

\subsubsection{Polyethylenimine}

Polyethylenimine (PEI) is a polymer that consists of repeating amine group with two carbon spacers with melting point of $73-75^{\circ} \mathrm{C}$ [26]. In general, PEI has been applied in polymer composite coatings because of its positively charged nature, thereby not only acting as binder but also enhancing the corrosion resistance of biodegradable metals. Cai et al., reported the 
fabrication of anti-corrosive layer-by-layer coating composed of polyethylene imine (PEI), polystyrene sulfonate (PSS) and 8-hydroxyquinoline (8HQ) on AZ91D Mg alloys [99]. The corrosion resistance of the coating on the alloy was studied by electrochemical measurements which showed the corrosion resistance for 4 days in $\mathrm{mSBF}$ (modified-SBF). Further, biocompatibility of coating was evaluated by studying the alkaline phosphatase activity of osteoblast cells, which indicated the higher osteo-differentiation when compared to uncoated Mg alloys. Although the number of studies on PEI is limited, but it shows promise as a potential protective coating for $\mathrm{Mg}$ and its alloys for orthopaedic applications.

\subsection{Natural polymers coatings}

Natural polymers such as collagen, chitosan, stearic acid and serum albumin have been studied as coatings on the surface of $\mathrm{Mg}$ and its alloys for anti-corrosive as well as biocompatible properties $[100,101]$. In comparison to sol-gel and synthetic poly-esters, natural polymers exhibit excellent biocompatibility due to their biomimetic nature [101]. For example, extracellular cell matrix (ECM) components possess cell specific domains such as RGD (Arg-gly-Asp) sequence which help in cell attachment [101]. Therefore, natural polymer based coatings on implanted material enhance the interactions between the implant surface and surrounding tissue matrix, thereby expediting the regeneration of tissues [22]. These polymers can also use for surface modifications, hydrogel scaffold synthesis and housing drugs for delivery [102]. Currently, the corrosion resistance of biopolymer is poor when compared to sol-gel and synthetic-polyester based coatings, and improvement would require in depth research work. The list of natural polymers coated on $\mathrm{Mg}$ and its alloys to study the corrosion resistance is given in Table 5. This section reviews the surface modifications of $\mathrm{Mg}$ and its alloys by natural polymers coatings to improve the corrosion resistance and biocompatibility. 


\subsubsection{Collagen coatings}

Collagen is the major component of extracellular materials of bone matrix. Many reports have demonstrated that collagen type-I provides a favourable surface for cell adhesion, functions and cell proliferation of bone related-cells [103]. It is expected that a collagen coating on $\mathrm{Mg}$ and its alloy may be suitable for corrosion resistance, although very few reports are available.

Wang et al, studied the corrosion resistance and biocompatibility of Poly(L-lactic acid)/hydroxyapatite/ collagen composite coatings on AZ31 $\mathrm{Mg}$ alloys for orthopaedic applications [104]. They found that natural polymers like collagen degrades too fast to provide any corrosion resistance to $\mathrm{Mg}$, whereas PLLA degrades through an autocatalytic effect resulting in a localised excessive acidic environment, where its hydrophobicity hampers the cell compatibility. In this disadvantages of composite of Hydroxy apatite (HAP)/collagen and PLLA have been offset by considering their respective advantages; Firstly, affinity of biomimetic apatite with collagen and their biocompatibility with body fluid is favourable; secondly, the porous architecture created by collagen/HAP enhances the wettability of PLLA, thereby benefiting the adhesion, cell proliferation and differentiation. It was shown that with increasing the mass ratio of PLLA/HA/C (C: collagen) the corrosion resistance increased as compared to bare $\mathrm{Mg}$ and PLLA coated alloy. Likewise, the overall change in $\mathrm{pH}$ was controlled with PLLA/HAC when compared to bare Mg AZ91 alloy.

\subsubsection{Chitosan coatings}

Chitosan coating is generally non-toxic and can play an important function as an adhesive basal matrix for growing cells during peri-implant healing process and also enhances the corrosion resistance of biodegradable metal [105]. Gu et al., studied the surface modification of the Mg-1Ca alloy by chitosan to slow down the corrosion in SBF [106]. Different layers of chitosan with varied molecular weight were dip coated on the $\mathrm{Mg}-1 \mathrm{Ca}$ alloy. It was shown 
that coatings produced by $1.5 \times 10^{5}$ and $2.7 \times 10^{5}$ molecular weight chitosan exhibited a smooth surface, whereas holes and defects were seen in coatings produced by $1.0 \times 10^{4}$ and $6.0 \times 10^{5}$ molecular weight equivalents. The alloy with six layers of chitosan (with molecular weight $2.7 \times 10^{5}$ ) was found to be smooth and intact in contrast to surface with one, three or nine layers of chitosan coatings. The lower corrosion of $\mathrm{Mg}$-1Ca alloy in terms of change in $\mathrm{pH}$ and hydrogen evolution gas was observed with six layers produced by $2.7 \times 10^{5}$ molecular weight chitosan.

Bai et al., studied the corrosion of MAO/Mg-Zn-Ca Magnesium alloy coated with a chitosan/Mg composite in vitro condition [107]. Coatings were prepared by $\mathrm{MAO} / \mathrm{Mg}-\mathrm{Zn}-\mathrm{Ca}$ alloy followed by dip coating in a chitosan solution. The corrosion study was evaluated by anodic polarisation in SBF. It was observed that anticorrosion performance increased significantly through composite coatings, however a single layer of chitosan coating provided limited corrosion enhancement. The corrosion studies showed nearly 3 fold increase in corrosion resistance with composite coatings when compared to bare alloy. Similarly, Liu et al., demonstrated the enhanced corrosion resistance of a WE43 Mg alloys, through layer-bylayer coating of chitosan and polystyrene polymers following MAO treatment [108]. Potentiodynamic polarisation and hydrogen evolution measurements showed significant improvement in the corrosion resistance of chitosan/polystyrene polymer coated MAO/WE43 alloy in SBF [108].

\subsubsection{Serum albumin coating}

Serum albumins are the most abundant proteins present in the circulatory system of various organisms [109]. They play as a major role in maintaining osmotic blood pressure, drug disposition and efficacy [110]. However, the anti-corrosive and biocompatibility properties of the serum albumin coating on $\mathrm{Mg}$ alloys have not been widely explored. Liu et al., showed 
that adsorption of bovine serum albumin (BSA) on AZ91 Mg alloy decreases the cathodic current and enhance the corrosion resistance in SBF [111]. It was observed that corrosion resistance increases with an increase in BSA concentration due to their blocking effect of the protein adsorbed layer which can suppresses the dissolution of AZ91 Mg alloys. In another study, Killian et al., presented an innovative method to cover the pure Mg with BSA via silane coupling chemistry [112]. They used ascorbic acid as a linker and 3aminopropyltriethoxy silane (APTES) as a coupling agent for grafting BSA onto a pure $\mathrm{Mg}$ substrate with $\mathrm{Mg}$ samples directly steeped in albumin solution used as controls. It was observed that APTES-albumin-Mg sample was smoother with fewer defects than the steeped equivalent, as a result in less prone to corrosion. After being treated with SBF for 3 days, the surface of the steeped sample exhibited larger pits because of localised corrosion. The hydrogen gas evolution decreased from $0.12 \mathrm{ml} / \mathrm{cm}^{2} /$ day for the polished $\mathrm{Mg}$ samples to $0.075 \mathrm{ml} / \mathrm{cm}^{2} /$ day after APTES-albumin treated $\mathrm{Mg}$. This indicated that albumin coatings attached through silane linker enhanced the alloy corrosion resistance and is a useful method for preparing other protein based biocompatible coatings on $\mathrm{Mg}$ alloy.

In general, surface modifications with natural polymers have shown to improve the corrosion resistance and biocompatibility properties of $\mathrm{Mg}$ and its alloys but literature reports for orthopaedic applications are limited. This indicates that the development of these coatings is in its infancy. As natural polymers are abundant, other kinds of natural polymers such as alginate agar, cellulose, dextran, chitin, casein, chondroitin sulfate etc. offer a wealth of coating opportunities.

\subsection{Osteoinductive factor loaded coatings}

In an attempt to overcome the limitations of $\mathrm{Mg}$ and its alloy for orthopaedic applications, protective coatings loaded with bone growth stimulating factors have been employed. The synergistic prevention of corrosion with the release of osteoinductive factors for accelerated 
healing at the implant site in bone are attractive [113]. However, the concept of drug eluting orthopaedic implant is relatively unexplored to date with limited literature. This contracts with drug loaded polymer coatings which have been developed extensively in biomedical devices such as cardiovascular stents, catheters etc.

Luo et al., reported the electrochemical deposition of conducting polymer coatings in ionic liquids on pure $\mathrm{Mg}$ loaded with an anti-inflammatory dexamethasone drug (Figure 3a and b) [113]. The authors argued that the ionic liquid is a highly conductive and stable, enabling the conductive polymer coatings to be electrodeposited on the $\mathrm{Mg}$ under mild conditions. The conducting polymer chosen (3,4-ethylenedioxythiophene) (PEDOT) was electrodeposited uniformly and improved the corrosion resistance of $\mathrm{Mg}$ significantly. The corrosion studies claimed a $50 \%$ decrease in current density for PEDOT coated $\mathrm{Mg}$ over bare $\mathrm{Mg}$. Additionally, the PEDOT coating was loaded with dexamethasone during electrodeposition and sustained release of the drug was controlled through electrochemical stimulus. Hence, by employing conducting polymer coating loaded with a drug, both corrosion resistance and biocompatibility were achieved.

\section{Potential challenges in surface modifications on Mg based alloys}

The corrosion mechanism of $\mathrm{Mg}$ and its alloying elements still faces several challenges. For example, Mg-based alloys containing rare-earth metals are important structural materials, as they combine low density with high-strength properties, but have different corrosion behaviour. Furthermore, the bio-incompatibility of the alloying elements create an unfavourable environment for the bone healing process, which is considered as a big challenge in the surface modification on $\mathrm{Mg}$ based alloys. Therefore, it is essential to investigate the corrosion resistance together with the biocompatible properties of alloying elements which might be applied to the development of orthopaedic Mg based implants. 
In the past decade, polymeric deposit coatings for the corrosion protection and biocompatibility are being investigated, and are applied in the commercial applications [114]. However, formulations of new and improved polymer which can offer enhanced corrosion resistance to $\mathrm{Mg}$ and its alloys still faces several challenges. The interface properties of polymeric coatings such as adhesion, delamination and the choice of base metal applied for studying the efficiency of coatings are the important factors for the quality and stability of coatings [115]. However, adhesion test for evaluating the stability and feasibility of polymer coatings have rarely been performed in the reported literature. Additionally, important parameters like $\mathrm{pH}$, solvents, temperature, electrolytes, kinetics of hydrolysis, pin hole formation, crystalline temperature are all of prime importance for the overall understanding of the coating / film formation on $\mathrm{Mg}$ based alloys. Collectively, the above-mentioned concerns could play an important role in large scale industrial production of $\mathrm{Mg}$ based orthopaedic implants.

Furthermore, new polymeric material and multiple component systems might be a future of the deposit coatings on $\mathrm{Mg}$ based alloys. The major advantage of synthetic polyesters (e.g PLGA, PCL, PLA) and sol-gel based is the ease of chemical derivatisation [116]. This could allow the synthesis of new polymer with desired properties such as enhanced mechanical properties, low hydrolysis rate and reduced toxicity. In addition, the blend of two or more polymers with desired characteristics or layer-by-layer coating of different polymers can also be incorporated in coating systems, in order to achieve stable, anti-corrosive and biocompatible deposit coatings for orthopaedic applications.

\section{Conclusions}

Despite of the immense potential of biodegradable $\mathrm{Mg}$ alloys for orthopaedic applications, the major disadvantage is their high corrosion rate, thereby creating bio-incompatible 
environment in the surrounding tissues. In order to overcome these drawbacks, strategies such as the effect of alloying elements and polymeric surface modifications of $\mathrm{Mg}$ and its alloys have been discussed. Based on the numerous research carried out, it is concluded that alloying elements such as $\mathrm{Al}, \mathrm{Ca}, \mathrm{Mn}$ etc., can react with $\mathrm{Mg}$ to form intermetallic phases which can dissolve in grain matrix or distribute along the grain boundary, thereby influencing the mechanical properties and corrosion behaviour of $\mathrm{Mg}$ based alloys. For some elements such as $\mathrm{Ca}$ and $\mathrm{Zn}$, the corrosion resistance depends upon their concentration in $\mathrm{Mg}$ alloys. Furthermore, the biocompatibility of these alloying elements on bone related cells is an important factor, and the implant should not show cell toxicity.

Therefore, in depth investigation is required to design the corrosion resistant and biocompatible $\mathrm{Mg}$ based alloys for orthopaedic applications. Recent research on the effect of polymer deposit coatings on corrosion behaviour and biocompatible properties of $\mathrm{Mg}$ alloys shows that sol-gel and synthetic polyester based coatings have significantly improved the corrosion resistant. Numerous studies also highlighted the improvement in corrosion properties of natural polymer coatings by incorporating the synthetic polymers. Furthermore, sol-gel and synthetic poly-ester coatings have shown the capability as local drug delivery platforms, however, there are very limited studies are carried out in the area. Therefore, novel strategies need to be designed, which could exploit the multifunctional coatings for the development of potential biodegradable orthopaedic $\mathrm{Mg}$ based implants.

\section{References}

[1] G.E.J. Poinern, S. Brundavanam, D. Fawcett, Biomedical magnesium alloys: a review of material properties, surface modifications and potential as a biodegradable orthopaedic implant, American Journal of Biomedical Engineering, 2 (2012) 218-240. 
[2] M.P. Staiger, A.M. Pietak, J. Huadmai, G. Dias, Magnesium and its alloys as orthopedic biomaterials: a review, Biomaterials, 27 (2006) 1728-1734.

[3] R. Murugan, S. Ramakrishna, Development of nanocomposites for bone grafting, Composites Science and Technology, 65 (2005) 2385-2406.

[4] X. Ye, Z.T.H. Tse, G. Tang, G. Song, Mechanical properties and phase transition of biomedical titanium alloy strips with initial quasi-single phase state under high-energy electropulses, Journal of the Mechanical Behavior of Biomedical Materials, 42 (2015) 100115.

[5] F. Witte, The history of biodegradable magnesium implants: a review, Acta Biomaterialia, 6 (2010) 1680-1692.

[6] E. Crubézy, P. Murail, L. Girard, J.P. Bernadou, False teeth of the Roman world, Nature, 391 (1998) 29-29.

[7] B.D. Ratner, A.S. Hoffman, F.J. Schoen, J.E. Lemons, Biomaterials science: an introduction to materials in medicine, Academic Press, 2004.

[8] Y. F. Zheng, X. Gu, F. Witte, Biodegradable metals, Materials Science and Engineering: R: Reports, 77 (2014) 1-34.

[9] X. Ye, L. Wang, Z.T.H Tse, G. Tang, G. Song, Effects of high-energy electro-pulsing treatment on microstructure, mechanical properties and corrosion behavior of $\mathrm{Ti}-6 \mathrm{Al}-4 \mathrm{~V}$ alloy, Materials Science and Engineering: C, 49 (2015) 851-860.

[10] A.M Rashmir-Raven, D. Richardson, H. Aberman, D. J. De Young, The response of cancellous and cortical canine bone to hydroxylapatite-coated and uncoated titanium rods, Journal of Applied Biomaterials, 6 (1995) 237-242.

[11] J. Nagels, M. Stokdijk, P.M. Rozing, Stress shielding and bone resorption in shoulder arthroplasty, Journal of Shoulder and Elbow Surgery, 12 (2003) 35-39. 
[12] G. Ryan, A. Pandit, D.P. Apatsidis, Fabrication methods of porous metals for use in orthopaedic applications, Biomaterials, 27 (2006) 2651-2670.

[13] B.V. Krishna, W. Xue, S. Bose, A. Bandyopadhyay, Engineered porous metals for implants, JOM, 60 (2008) 45-48.

[14] C. Lhotka, T. Szekeres, I. Steffan, K. Zhuber, K. Zweymüller, Four-year study of cobalt and chromium blood levels in patients managed with two different metal-on-metal total hip replacements, Journal of Orthopaedic Research, 21 (2003) 189-195.

[15] J. Walker, S. Shadanbaz, T.B. Woodfield, M.P. Staiger, G.J. Dias, Magnesium biomaterials for orthopedic application: a review from a biological perspective, Journal of Biomedical Materials Research Part B: Applied Biomaterials, 102 (2014) 1316-1331.

[16] P. Ducheyne, L.L. Hench, A.Kagan II, M. Martens, A. Bursens, J.C. Mulier, Effect of hydroxyapatite impregnation on skeletal bonding of porous coated implants, Journal of Biomedical Materials Research, 14 (1980) 225-237.

[17] H. Yoshikawa, N. Tamai, T. Murase, A. Myoui, Interconnected porous hydroxyapatite ceramics for bone tissue engineering, Journal of the Royal Society Interface, 13 (2008) 1-8.

[18] S. Itoh, M. Kikuchi, Y. Koyama, H.N. Matumoto, K. Takakuda, K. Shinomiya, J. Tanaka, Development of a novel biomaterial, hydroxyapatite/collagen (HAp/Col) composite for medical use, Bio-medical Materials and Engineering, 15 (2004) 29-41.

[19] R. Rojaee, M. Fathi, K. Raeissi, Controlling the degradation rate of AZ91 magnesium alloy via sol-gel derived nanostructured hydroxyapatite coating, Materials Science and Engineering: C, 33 (2013) 3817-3825.

[20] E.M. Zahrani, M.H. Fathi, A.M. Alfantazi, Sol-gel derived nanocrystalline fluoridated hydroxyapatite powders and nanostructured coatings for tissue engineering applications, Metallurgical and Materials Transactions A, 42 (2011) 3291-3309. 
[21] R. Gadow, A. Killinger, N. Stiegler, Hydroxyapatite coatings for biomedical applications deposited by different thermal spray techniques, Surface and Coatings Technology, 205 (2010) 1157-1164.

[22] M. Swetha, K. Sahithi, A. Moorthi, N. Srinivasan, K. Ramasamy, N. Selvamurugan, Biocomposites containing natural polymers and hydroxyapatite for bone tissue engineering, International Journal of Biological Macromolecules, 47 (2010) 1-4.

[23] B.L. Guo, P.X. Ma, Synthetic biodegradable functional polymers for tissue engineering: a brief review, Science China Chemistry, 57 (2014) 490-500.

[24] P.A. Gunatillake, R. Adhikari, Biodegradable synthetic polymers for tissue engineering, European Cells and Materials., 5 (2003) 1-16.

[25] D.S. Kohane, R. Langer, Polymeric biomaterials in tissue engineering, Pediatric Research, 63 (2008) 487-491.

[26] Y. Zhao, G. Wu, J. Jiang, H.M. Wong, K.W. Yeung, P.K. Chu, Improved corrosion resistance and cytocompatibility of magnesium alloy by two-stage cooling in thermal treatment, Corrosion Science, 59 (2012) 360-365.

[27] F. Witte, V. Kaese, H. Haferkamp, E. Switzer, A. Meyer-Lindenberg, C.J. Wirth, H. Windhagen, In vivo corrosion of four magnesium alloys and the associated bone response, Biomaterials, 26 (2005) 3557-3563.

[28] E. Ghali, Corrosion resistance of aluminum and magnesium alloys: understanding, performance, and testing, John Wiley \& Sons, 2010.

[29] G. Song, Recent progress in corrosion and protection of magnesium alloys, Advanced Engineering Materials, 7 (2005) 563-586.

[30] E. Zhang, H. Chen, F. Shen, Biocorrosion properties and blood and cell compatibility of pure iron as a biodegradable biomaterial, Journal of Materials Science: Materials in Medicine, 21 (2010) 2151-2163. 
[31] S. Song, G.L. Song, W. Shen, M. Liu, Corrosion and electrochemical evaluation of coated magnesium alloys, Corrosion, The Journal of Science and Engineering, 68 (2012) 015005-11.

[32] G. Song, Control of biodegradation of biocompatable magnesium alloys, Corrosion Science, 49 (2007) 1696-1701.

[33] Y. Xin, T. Hu, P.K. Chu, In vitro studies of biomedical magnesium alloys in a simulated physiological environment: a review, Acta Biomaterialia, 7 (2011) 1452-1459.

[34] R. Rettig, S. Virtanen, Time-dependent electrochemical characterization of the corrosion of a magnesium rare-earth alloy in simulated body fluids, Journal of Biomedical Materials Research Part A, 85 (2008) 167-175.

[35] Y. Xin, K. Huo, H. Tao, G. Tang, P.K. Chu, Influence of aggressive ions on the degradation behavior of biomedical magnesium alloy in physiological environment, Acta Biomaterialia, 4 (2008) 2008-2015.

[36] R. Zeng, W. Dietzel, F. Witte, N. Hort, C. Blawert, Progress and challenge for magnesium alloys as biomaterials, Advanced Engineering Materials, 10 (2008) B3-B14.

[37] R.C. Zeng, J. Zhang, W.J. Huang, W. Dietzel, K.U. Kainer, C. Blawert, K.E. Wei, Review of studies on corrosion of magnesium alloys, Transactions of Nonferrous Metals Society of China, 16 (2006) s763-s771.

[38] G. Song, A. Atrens, Understanding magnesium corrosion-a framework for improved alloy performance. Advanced Engineering Materials, 5 (2003) 837-858.

[39] E. Ghali, W. Dietzel, K.U. Kainer, General and localized corrosion of magnesium alloys: a critical review, Journal of Materials Engineering and Performance, 13 (2004) 7-23.

[40] L.J. Liu, M. Schlesinger, Corrosion of magnesium and its alloys, Corrosion Science, 51 (2009) 1733-1737. 
[41] X.N. Gu, W.R. Zhou, Y.F. Zheng, Y. Cheng, S.C. Wei, S.P. Zhong, T.F. Xi, L.J. Chen, Corrosion fatigue behaviors of two biomedical Mg alloys-AZ91D and WE43-in simulated body fluid, Acta Biomaterialia, 6 (2010) 4605-4613.

[42] K.J. Bundy, C.J. Williams, R.E. Luedemann, Stress-enhanced ion release - the effect of static loading, Biomaterials, 12 (1991) 627-639.

[43] K.J. Bundy, M.A. Vogelbaum, V.H. Desai, The influence of static stress on the corrosion behavior of $316 \mathrm{~L}$ stainless steel in Ringer's solution, Journal of Biomedical Materials Research, 20 (1986) 493-505.

[44] S. Zhang, X. Zhang, C. Zhao, J. Li, Y. Song, C. Xie, H. Tao, Y. Zhang, Y. He, Y. Jiang, Y.Bian, Research on an $\mathrm{Mg}-\mathrm{Zn}$ alloy as a degradable biomaterial, Acta Biomaterialia, 6 (2010) 626-640.

[45] Q. Wang, L. Tan, W. Xu, B. Zhang, K. Yang, Dynamic behaviors of a Ca-P coated AZ31B magnesium alloy during in vitro and in vivo degradations, Materials Science and Engineering: B, 176 (2011) 1718-1726.

[46] M. B. Kannan, R.K. Singh Raman, F. Witte, C. Blawert, W. Dietzel, Influence of circumferential notch and fatigue crack on the mechanical integrity of biodegradable magnesium-based alloy in simulated body fluid, Journal of Biomedical Materials Research Part B: Applied Biomaterials, 96 (2011) 303-309.

[47] G. Song, A. Atrens, X. Wu, B. Zhang, Corrosion behaviour of AZ21, AZ501 and AZ91 in sodium chloride, Corrosion Science, 40 (1998) 1769-1791.

[48] Y.C. Lee, A.K. Dahle, D.H StJohn, The role of solute in grain refinement of magnesium, Metallurgical and Materials Transactions A, 31 (2000) 2895-2906.

[49] Y. Ding, C. Wen, P. Hodgson, Y. Li, Effects of alloying elements on the corrosion behavior and biocompatibility of biodegradable magnesium alloys: a review, Journal of Materials Chemistry B, 2 (2014) 1912-1933. 
[50] D. Song, A.B. Ma, J.H. Jiang, P.H. Lin, D.H. Yang, J.F. Fan, Corrosion behaviour of bulk ultra-fine grained AZ91D magnesium alloy fabricated by equal-channel angular pressing, Corrosion Science, 53 (2011) 362-373.

[51] G.L. Song, A. Atrens, Corrosion mechanisms of magnesium alloys, Advanced Engineering Materials, 1 (1999) 11-33.

[52] Y.C. Li, M.H. Li, W.Y. Hu, P.D. Hodgson, C.E. Wen, Biodegradable Mg-Ca and MgCa-Y alloys for regenerative medicine, Materials Science Forum, Trans Tech Publications, 654 (2010) 2192-2195.

[53] K.H. Kim, N.D. Nam, J.G. Kim, K.S. Shin, H.C. Jung, Effect of calcium addition on the corrosion behavior of Mg-5Al alloy, Intermetallics, 19 (2011) 1831-1838.

[54] D.S. Yin, E.L. Zhang, S.Y. Zeng, Effect of Zn on mechanical property and corrosion property of extruded Mg-Zn-Mn alloy, Transactions of Nonferrous Metals Society of China, 18 (2008) 763-768.

[55] Y. Song, E.H. Han, D. Shan, C.D. Yim, B.S. You, The effect of Zn concentration on the corrosion behavior of Mg-xZn alloys, Corrosion Science, 65 (2012) 322-330.

[56] F. Witte, N. Hort, C. Vogt, S. Cohen, K.U. Kainer, R. Willumeit, F. Feyerabend, Degradable biomaterials based on magnesium corrosion, Current Opinion in Solid State and Materials Science, 12 (2008) 63-72.

[57] Y. Song, D. Shan, R. Chen, E.H. Han, Corrosion characterization of Mg-8Li alloy in $\mathrm{NaCl}$ solution, Corrosion Science, 51 (2009) 1087-1094.

[58] R.C. Zeng, L. Sun, Y.F. Zheng, H.Z. Cui, E.H. Han, Corrosion and characterisation of dual phase $\mathrm{Mg}-\mathrm{Li}-\mathrm{Ca}$ alloy in Hank's solution: the influence of microstructural features, Corrosion Science, 79 (2014) 69-82. 
[59] N. Hort, Y. Huang, D. Fechner, M. Störmer, C. Blawert, F. Witte, C. Vogt, H. Drücker, R. Willumeit, K.U. Kainer, F. Feyerabend, Magnesium alloys as implant materials-Principles of property design for Mg-RE alloys, Acta Biomaterialia, 6 (2010) 1714-1725.

[60] L.L. Rokhlin, Magnesium alloys containing rare earth metals: structure and properties, CRC Press, 2003.

[61] A.A. Luo, W. Wu, R.K. Mishra, L. Jin, A.K. Sachdev, W. Ding, Microstructure and mechanical properties of extruded magnesium-aluminum-cerium alloy tubes, Metallurgical and Materials Transactions A, 41 (2010) 2662-2674.

[62] F. Witte, H. Ulrich, M. Rudert, E. Willbold, Biodegradable magnesium scaffolds: Part 1: appropriate inflammatory response, Journal of Biomedical Materials Research Part A, 81 (2007) 748-756.

[63] F. Witte, H. Ulrich, C. Palm, E. Willbold, Biodegradable magnesium scaffolds: Part II: Peri-implant bone remodeling, Journal of Biomedical Materials Research Part A, 81 (2007) 757-765.

[64] F. Feyerabend, J. Fischer, J. Holtz, F. Witte, R. Willumeit, H. Drücker, C. Vogt, N. Hort, Evaluation of short-term effects of rare earth and other elements used in magnesium alloys on primary cells and cell lines, Acta Biomaterialia, 6 (2010) 1834-1842.

[65] Z.L. Sun, J.C. Wataha, C.T. Hanks, Effects of metal ions on osteoblast-like cell metabolism and differentiation, Journal of Biomedical Materials Research, 34 (1997) 29-37. [66] L.J. Raggatt, N.C. Partridge, Cellular and molecular mechanisms of bone remodeling, Journal of Biological Chemistry, 285 (2010) 25103-25108.

[67] D. Wang, G.P. Bierwagen, Sol-gel coatings on metals for corrosion protection, Progress in Organic Coatings, 64 (2009) 327-338.

[68] J.D. Wright, N.A. Sommerdijk, Sol-gel materials: chemistry and applications, CRC Press, 2000. 
[69] M.T. Reetz, Entrapment of biocatalysts in hydrophobic sol-gel materials for use in organic chemistry, Advanced Materials, 9 (1997) 943-954.

[70] C.J. Brinker, G.W. Scherer, Sol-gel science: the physics and chemistry of sol-gel processing, Academic Press, 2013.

[71] L.L. Hench, Sol-gel silica: properties, processing and technology transfer, William Andrew, 1998.

[72] R.G. Hu, S. Zhang, J.F. Bu, C.J. Lin, G.L. Song, Recent progress in corrosion protection of magnesium alloys by organic coatings, Progress in Organic Coatings, 73 (2012) 129-141.

[73] S. Gaur, R.S. Raman, A.S. Khanna, In vitro investigation of biodegradable polymeric coating for corrosion resistance of $\mathrm{Mg}-6 \mathrm{Zn}-\mathrm{Ca}$ alloy in simulated body fluid, Materials Science and Engineering: C, 42 (2014) 91-101.

[74] A.N. Khramov, V.N. Balbyshev, L.S. Kasten, R.A. Mantz, Sol-gel coatings with phosphonate functionalities for surface modification of magnesium alloys, Thin Solid Films, 514 (2006) 174-181.

[75] P. Shi, W.F. Ng, M.H. Wong, F.T. Cheng, Improvement of corrosion resistance of pure magnesium in Hanks' solution by microarc oxidation with sol-gel $\mathrm{TiO}_{2}$ sealing, Journal of Alloys and Compounds, 469 (2009) 286-292.

[76] M. Lalk, J. Reifenrath, D. Rittershaus, D. Bormann, A. Meyer-Lindenberg, Biocompatibility and degradation behaviour of degradable magnesium sponges coated with bioglass-method establishment within the framework of a pilot study. Biokompatibilität und Degradationsverhalten von degradablen, bioglas-beschichteten MagnesiumschwämmenMethodenetablierung im Rahmen einer Pilotstudie, Materialwissenschaft und Werkstofftechnik, 41 (2010) 1025-1034.

[77] T. Ishizaki, Y. Masuda, M. Sakamoto, Corrosion resistance and durability of superhydrophobic surface formed on magnesium alloy coated with nanostructured cerium 
oxide film and fluoroalkylsilane molecules in corrosive $\mathrm{NaCl}$ aqueous solution, Langmuir, 27 (2011) 4780-4788.

[78] C.M. Agrawal, Reconstructing the human body using biomaterials, The Journal of The Minerals, Metals \& Materials Society, 50 (1998) 31-35.

[79] J.C. Middleton, A.J. Tipton, Synthetic biodegradable polymers as orthopedic devices, Biomaterials, 21 (2000) 2335-2346.

[80] C.L. Zhao, S.X. Zhang, C.H. He, J.N. Li, B.L. Zhang, X.N. Zhang, Study of PLGA coating on bio-absorbable Mg alloy [J], Journal of Functional Materials, 6 (2008) 030.

[81] R.A. Miller, J.M. Brady, D.E. Cutright, Degradation rates of oral resorbable implants (polylactates and polyglycolates): rate modification with changes in PLA/PGA copolymer ratios, Journal of Biomedical Materials Research, 11 (1977) 711-719.

[82] L.S. Nair, C.T. Laurencin, Biodegradable polymers as biomaterials, Progress in Polymer Science, 32 (2007) 762-798.

[83] Y. Takahashi, M. Yamamoto, Y. Tabata, Enhanced osteoinduction by controlled release of bone morphogenetic protein- 2 from biodegradable sponge composed of gelatin and $\beta$ tricalcium phosphate, Biomaterials, 26 (2005) 4856-4865.

[84] N. Saito, N. Murakami, J. Takahashi, H. Horiuchi, H. Ota, H. Kato, T. Okada, K. Nozaki, K. Takaoka, Synthetic biodegradable polymers as drug delivery systems for bone morphogenetic proteins, Advanced Drug Delivery Reviews, 57 (2005) 1037-1048.

[85] P. Shi, B. Niu, E. Shanshan, Y. Chen, Q. Li, Preparation and characterization of PLA coating and PLA/MAO composite coatings on AZ31 magnesium alloy for improvement of corrosion resistance, Surface and Coatings Technology, 262 (2015) 26-32.

[86] R.C. Zeng, W.C. Qi, Y.W. Song, Q.K. He, H.Z. Cui, E.H. Han, In vitro degradation of MAO/PLA coating on Mg-1.21 Li-1.12 Ca-1.0 Y alloy, Frontiers of Materials Science, 8 (2014) 343-353. 
[87] Y. Chen, Y. Song, S. Zhang, J. Li, C. Zhao, X. Zhang, Interaction between a high purity magnesium surface and PCL and PLA coatings during dynamic degradation, Biomedical Materials, 6 (2011) 025005.

[88] A. Alabbasi, S. Liyanaarachchi, M.B. Kannan, Polylactic acid coating on a biodegradable magnesium alloy: An in vitro degradation study by electrochemical impedance spectroscopy, Thin Solid Films, 520 (2012) 6841-6844.

[89] C. Wu, Y. Ramaswamy, P. Boughton, H. Zreiqat, Improvement of mechanical and biological properties of porous $\mathrm{CaSiO}_{3}$ scaffolds by poly (d, l-lactic acid) modification, Acta Biomaterialia, 4 (2008) 343-353.

[90] K. Rezwan, Q.Z. Chen, J.J. Blaker, A.R. Boccaccini, Biodegradable and bioactive porous polymer/inorganic composite scaffolds for bone tissue engineering, Biomaterials, 27 (2006) 3413-3431.

[91] K. Leja, G. Lewandowicz, Polymer biodegradation and biodegradable polymers-a review, Polish Journal of Environmental Studies, 19 (2010) 255-266.

[92] A.M. Reed, D.K. Gilding, Biodegradable polymers for use in surgery-poly (glycolic)/poly (Iactic acid) homo and copolymers: 2. In vitro degradation, Polymer, 22 (1981) 494-498.

[93] N.J. Ostrowski, B. Lee, A. Roy, M. Ramanathan, P.N. Kumta, Biodegradable poly (lactide-co-glycolide) coatings on magnesium alloys for orthopedic applications, Journal of Materials Science: Materials in Medicine, 24 (2013) 85-96.

[94] J.Y. Chen, X.B. Chen, J.L. Li, B. Tang, N. Birbilis, X. Wang, Electrosprayed PLGA smart containers for active anti-corrosion coating on magnesium alloy AMlite, Journal of Materials Chemistry A, 2 (2014) 5738-5743. 
[95] J.N. Li, P. Cao, X.N. Zhang, S.X. Zhang, Y.H. He, In vitro degradation and cell attachment of a PLGA coated biodegradable Mg-6Zn based alloy, Journal of Materials Science, 45 (2010) 6038-6045.

[96] M. Park, J.E. Lee, C.G. Park, S.H. Lee, H.K. Seok, Y.B. Choy, Polycaprolactone coating with varying thicknesses for controlled corrosion of magnesium, Journal of Coatings Technology and Research, 10 (2013) 695-706.

[97] L.H. Li, T.S. Narayanan, Y.K. Kim, Y.M. Kong, I.S. Park, T.S. Bae, M.H. Lee, Deposition of microarc oxidation-polycaprolactone duplex coating to improve the corrosion resistance of magnesium for biodegradable implants, Thin Solid Films, 562 (2014) 561-567. [98] J. Degner, F. Singer, L. Cordero, A.R. Boccaccini, S. Virtanen, Electrochemical investigations of magnesium in DMEM with biodegradable polycaprolactone coating as corrosion barrier, Applied Surface Science, 282 (2013) 264-270.

[99] K. Cai, X. Sui, Y. Hu, L. Zhao, M. Lai, Z. Luo, P. Liu, W. Yang, Fabrication of anticorrosive multilayer onto magnesium alloy substrates via spin-assisted layer-by-layer technique, Materials Science and Engineering: C, 31 (2011) 1800-1808.

[100] S.A. Sell, P.S. Wolfe, K. Garg, J.M. McCool, I.A. Rodriguez, G.L. Bowlin, The use of natural polymers in tissue engineering: a focus on electrospun extracellular matrix analogues, Polymers, 2 (2010) 522-553.

[101] H. Tan, K.G. Marra, Injectable, biodegradable hydrogels for tissue engineering applications, Materials, 3 (2010) 1746-1767.

[102] S. Bose, M. Roy, A. Bandyopadhyay, Recent advances in bone tissue engineering scaffolds, Trends in Biotechnology, 30 (2012) 546-554.

[103] D. Mushahary, C. Wen, J.M. Kumar, J. Lin, N. Harishankar, P. Hodgson, G. Pande, Y. $\mathrm{Li}$, Collagen type-I leads to in vivo matrix mineralization and secondary stabilization of $\mathrm{Mg}-$ Zr-Ca alloy implants, Colloids and Surfaces B: Biointerfaces, 122 (2014) 719-728. 
[104] Z.L. Wang, Y.H. Yan, T. Wan, H. Yang, Poly (L-lactic acid)/hydroxyapatite/collagen composite coatings on AZ31 magnesium alloy for biomedical application, Proceedings of the Institution of Mechanical Engineers, Part H: Journal of Engineering in Medicine, 227 (2013) 1094-1103.

[105] A.M. Fekry, A.A. Ghoneim, M.A. Ameer, Electrochemical impedance spectroscopy of chitosan coated magnesium alloys in a synthetic sweat medium, Surface and Coatings Technology, 238 (2014) 126-132.

[106] X N Gu, Y F Zheng, Q X Lan, Y Cheng, Z X Zhang, T F Xi, D Y Zhang, Z. Li, X. Gu, S. Lou, Y. Zheng, Surface modification of an $\mathrm{Mg}-1 \mathrm{Ca}$ alloy to slow down its biocorrosion by chitosan, Biomed. Mater., 4 (2009) 1-4.

[107] K. Bai, Y. Zhang, Z. Fu, C. Zhang, X. Cui, E. Meng, S. Guan, J. Hu, Fabrication of chitosan/magnesium phosphate composite coating and the in vitro degradation properties of coated magnesium alloy, Materials Letters, 73 (2012) 59-61.

[108] P. Liu, X. Pan, W. Yang, K. Cai, Y. Chen, Improved anticorrosion of magnesium alloy via layer-by-layer self-assembly technique combined with micro-arc oxidation, Materials Letters, 75 (2012) 118-121.

[109] V.L. Vilker, C.K. Colton, K.A. Smith, The osmotic pressure of concentrated protein solutions: effect of concentration and $\mathrm{pH}$ in saline solutions of bovine serum albumin, Journal of Colloid and Interface Science, 79 (1981) 548-566.

[110] M. Rahimnejad, M. Jahanshahi, G. Najafpour, Production of biological nanoparticles from bovine serum albumin for drug delivery, African Journal of Biotechnology, 5 (2006) 1918-1923.

[111] C. Liu, Y. Xin, X. Tian, P.K. Chu, Degradation susceptibility of surgical magnesium alloy in artificial biological fluid containing albumin, Journal of Materials Research, 22 (2007) 1806-1814. 
[112] M.S. Killian, V. Wagener, P. Schmuki, S. Virtanen, Functionalization of metallic magnesium with protein layers via linker molecules, Langmuir, 26 (2010) 12044-12048.

[113] X. Luo, X.T. Cui, Electrochemical deposition of conducting polymer coatings on magnesium surfaces in ionic liquid, Acta Biomaterialia, 7 (2011) 441-446.

[114] B. Klocke, U. Bayer, Implant and method for production of the same, U.S. Patent $8,709,0732014$.

[115] Q. Wei, T. Becherer, P.L.M. Noeske, I. Grunwald, R. Haag, A universal approach to crosslinked hierarchical polymer multilayers as stable and highly effective antifouling coatings, Advanced Materials, 26 (2014) 2688-2693.

[116] M. Garinot, V. Fiévez, V. Pourcelle, F. Stoffelbach, A.D. Rieux, L. Plapied, I. Theate, H. Freichels, C. Jérôme, J. Marchand-Brynaert, Y.J. Schneider, V. Preat, PEGylated PLGAbased nanoparticles targeting M cells for oral vaccination, Journal of Controlled Release, 120 (2007) 195-204.

[117] J.Y. Rho, L. Kuhn-Spearing, P. Zioupos, Mechanical properties and the hierarchical structure of bone, Medical Engineering \& Physics, 20 (1998) 92-102.

[118] K. Kubota, M. Mabuchi, K. Higashi, Review processing and mechanical properties of fine-grained magnesium alloys, Journal of Materials Science, 34 (1999) 2255-2262.

[119] A. Deschamps, F. Livet, Y. Brechet, Influence of predeformation on ageing in an AlZn-Mg alloy-I. Microstructure evolution and mechanical properties, Acta Biomaterialia, 47 (1998) 281-292.

[120] T. Rzychoń, A. Kiełbus, Microstructure of WE43 casting magnesium alloys, Journal of Achievements in Materials and Manufacturing Engineering, 21 (2007) 31-34.

[121] H. Hermawan, D. Dubé, D. Mantovani, Degradable metallic biomaterials: design and development of Fe-Mn alloys for stents, Journal of Biomedical Materials Research Part A, 93 (2010) 1-11. 
[122] R. Michalik, The effect of modification with rare earth elements on $\mathrm{ZnAl} 22 \mathrm{Cu} 3$ alloy structure and mechanical properties/Wpływ Modyfikacji Pierwiastkami Ziem Rzadkich Na Strukture I Własciwosci Mechaniczne Stopu ZnA122Cu3, Archives of Metallurgy and Materials, 58 (2013) 49-53.

[123] E. Menthe, A. Bulak, J. Olfe, A. Zimmermann, K.T. Rie, Improvement of the mechanical properties of austenitic stainless steel after plasma nitriding, Surface and Coatings Technology, 133 (2000) 259-263.

[124] M. Niinomi, Mechanical properties of biomedical titanium alloys, Materials Science and Engineering: A, 243 (1998) 231-236.

[125] W.A. Brantley, P.F. Herman, Cobalt-chromium and nickel-chromium alloys for removable prosthodontics, part 1: mechanical properties, Journal of Prosthodontics, 2 (1993) 144-150.

[126] D. Munz, T. Fett, Ceramics: mechanical properties, failure behaviour, materials selection, Springer Science \& Business Media, 2013.

[127] P. Fratzl, K. Misof, I. Zizak, G. Rapp, H. Amenitsch, S. Bernstorff, Fibrillar structure and mechanical properties of collagen, Journal of Structural Biology, 122 (1998) 119-122.

[128] L. Leung, C. Chan, S. Baek, H. Naguib, Comparison of morphology and mechanical properties of PLGA bioscaffolds, Biomedical Materials, 3 (2008) 025006.

[129] D. Kurniawan, F.M. Nor, H.Y. Lee, J.Y. Lim, Elastic properties of polycaprolactone at small strains are significantly affected by strain rate and temperature, Proceedings of the Institution of Mechanical Engineers, Part H: Journal of Engineering in Medicine, 225 (2011) 1015-1020.

[130] G. Perego, G.D. Cella, C. Bastioli, Effect of molecular weight and crystallinity on poly (lactic acid) mechanical properties, Journal of Applied Polymer Science, 59 (1996) 37-43. 
[131] J. Walker, S. Shadanbaz, N.T. Kirkland, E. Stace, T. Woodfield, M.P. Staiger, G.J. Dias, Magnesium alloys: predicting in vivo corrosion with in vitro immersion testing, Journal of Biomedical Materials Research. Part B, Applied Biomaterials, 100 (2012) 1134-1141.

[132] A. Chaya, S. Yoshizawa, K. Verdelis, N. Myers, B.J. Costello, D.T. Chou, S. Pal, S. Maiti, P.N. Kumta, C. Sfeir, In vivo study of magnesium plate and screw degradation and bone fracture healing, Acta Biomaterialia, 18 (2015) 262-269.

[133] N.I.Z. Abidin, B. Rolfe, H. Owen, J. Malisano, D. Martin, J. Hofstetter, P.J. Uggowitzer, A. Atrens, The in vivo and in vitro corrosion of high-purity magnesium and magnesium alloys WZ21 and AZ91, Corrosion Science, 75 (2013) 354-366.

[134] Y. Wang, M. Wei, J. Gao, J. Hu, Y. Zhang, Corrosion process of pure magnesium in simulated body fluid, Materials letters, 62 (2008) 2181-2184.

[135] N.T. Kirkland, N. Birbilis, M.P. Staiger, Assessing the corrosion of biodegradable magnesium implants: a critical review of current methodologies and their limitations, Acta Biomaterialia, 8 (2012) 925-936.

[136] N.I.Z. Abidin, D. Martin, A. Atrens, Corrosion of high purity Mg, AZ91, ZE41 and Mg2Zn0.2Mn in Hank's solution at room temperature, Corrosion Science, 53 (2011) 862872.

[137] Z. Wen, C. Wu, C. Dai, F. Yang, Corrosion behaviors of Mg and its alloys with different $\mathrm{Al}$ contents in a modified simulated body fluid, Journal of Alloys and Compounds, 488 (2009) 392-399.

[138] F. Witte, J. Fischer, J. Nellesen, H.A. Crostack, V. Kaese, A. Pisch, F. Beckmann, H. Windhagen, In vitro and in vivo corrosion measurements of magnesium alloys, Biomaterials, 27 (2006) 1013-1018. 
[139] D. Xue,Y. Yun, Z. Tan, Z. Dong, M.J.Schulz, In vivo and in vitro degradation behavior of magnesium alloys as biomaterials. Journal of Materials Science \& Technology, 28 (2012) 261-267.

[140] A.H.M. Sanchez, B.J. Luthringer, F. Feyerabend, R. Willumeit, Mg and Mg alloys: How comparable are in vitro and in vivo corrosion rates? A review, Acta Biomaterialia, 13 (2015) 16-31.

[141] B. Ullmann, J. Reifenrath, J.M. Seitz, D. Bormann, A. Meyer-Lindenberg, Influence of the grain size on the in vivo degradation behaviour of the magnesium alloy LAE442, Proceedings of the Institution of Mechanical Engineers, Part H: Journal of Engineering in Medicine, 227 (2013) 317-326.

[142] W.D. Mueller, M.L. Nascimento, M.F.L. De Mele, Critical discussion of the results from different corrosion studies of $\mathrm{Mg}$ and $\mathrm{Mg}$ alloys for biomaterial applications, Acta Biomaterialia, 6 (2010) 1749-1755.

[143] M. Thomann, C. Krause, D. Bormann, N. Von der Höh, H. Windhagen, A. Meyer-Lindenberg, Comparison of the resorbable magnesium. alloys LAE442 und MgCa0.8 concerning their mechanical properties, their progress of degradation and the bone-implant-contact after 12 months implantation duration in a rabbit model, Materialwissenschaft und Werkstofftechnik, 40 (2009) 82-87.

[144] A. Krause, N. Von der Höh, D. Bormann, C. Krause, F.W. Bach, H. Windhagen, A. Meyer-Lindenberg, Degradation behaviour and mechanical properties of magnesium implants in rabbit tibiae, Journal of Materials Science, 45 (2010) 624-632.

[145] W. Wlake, E. Hadasik, J. Przondziono, D. Kuc, I. Bednarczyk, G. Niewielski, Plasticity and corrosion resistance of magnesium alloy WE43, Archives of Materials Science and Engineering, 51 (2011) 16-24. 
[146] D. Liu, Y. Ding, T. Guo, X. Qin, C. Guo, S. Yu, S. Lin, Influence of fine-grain and solid-solution strengthening on mechanical properties and in vitro degradation of WE43 alloy, Biomedical Materials, 9 (2014) 015014.

[147] R.C. Zeng, W.C.Qi, Y.W. Song, Q.K. He, H.Z. Cui, E.H. Han, In vitro degradation of MAO/PLA coating on Mg-1.21Li-1.12Ca-1.0Y alloy, Frontiers of Materials Science, 8 (2014) 343-353.

[148] N. Ostrowski, B. Lee, N. Enick, B. Carlson, S. Kunjukunju, A. Roy, P.N. Kumta, Corrosion protection and improved cytocompatibility of biodegradable polymeric layer-bylayer coatings on AZ31 magnesium alloys, Acta Biomaterialia, 9 (2013) 8704-8713.

[149] X. Zhang, Q. Li, L. Li, P. Zhang, Z. Wang, F. Chen, Fabrication of hydroxyapatite/stearic acid composite coating and corrosion behavior of coated magnesium alloy, Materials Letters, 88 (2012) 76-78.

[150] C.H. Park, H.R. Pant, C.S. Kim, Effect on corrosion behavior of collagen film/fiber coated AZ31 magnesium alloy, Digest Journal of Nanomaterials and Biostructures, 8 (2013) $1227-1234$.

[151] J. Lévesque, H. Hermawan, D. Dubé, D. Mantovani, Design of a pseudo-physiological test bench specific to the development of biodegradable metallic biomaterials, Acta Biomaterialia, 4 (2008) 284-295. 


\section{Figures caption}

Figure 1. (I) Potentiodynamic curves of (a) bare magnesium alloy, and super hydrophobic coating on magnesium alloy after immersion in $5 \mathrm{wt} \% \mathrm{NaCl}$ aqueous solution for (b) 30, (c) 60, and (d) $180 \mathrm{~min}$. and (II) SEM images of the sample surfaces (a) before and after immersing in $5 \mathrm{wt} \% \mathrm{NaCl}$ aqueous solution for (b) 30, (c) 180, and (d) 1440 mins.( Source: Adapted from Ishikai et al.[77] with permission)

Figure 2. (I) Potentiodynamic studies of Mg6Zn coated and uncoated with PLGA in $0.9 \%$ $\mathrm{NaCl}$ (II) SEM image of cell morphology on $2 \%$ PLGA coated at different time points (a) 1 day, (b) 2 day, (c) 3 day and (d-f) cell morphology on uncoated Mg6Zn at same time points. (Source: Adapted from Li et al [95] with permission).

Figure 3. (a) Polarisation curves of bare $\mathrm{Mg}$ and $\mathrm{Mg}$ coated with PEDOT coating in $10 \mathrm{mM}$ PBS, pH 7.4 and, (b) Electrical stimulated accumulated drug release of the PEDOT/IL/Dex/Mg. (Source: Adapted from Luo et al. [113] with permission). 


\section{Figure 1:}
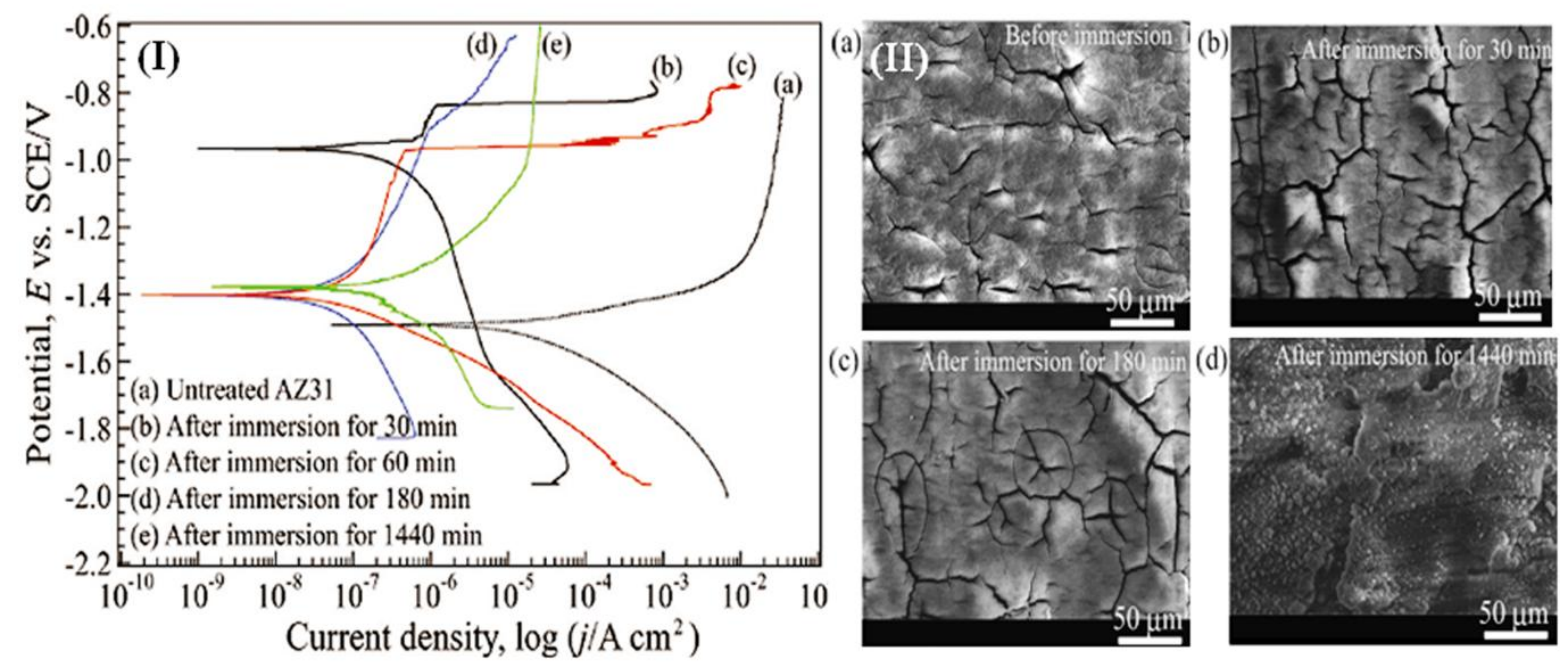
Figure 2
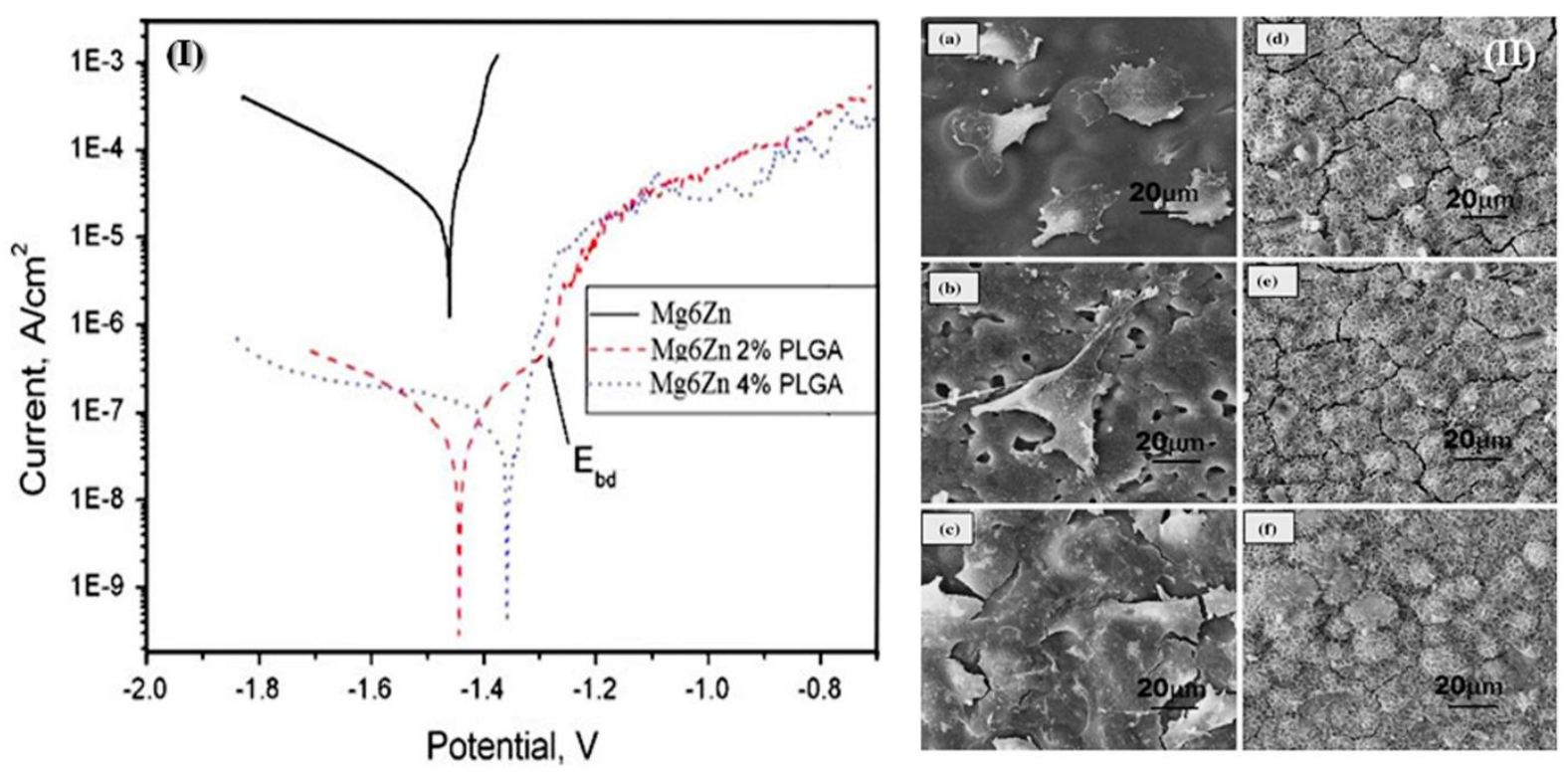
Figure 3:
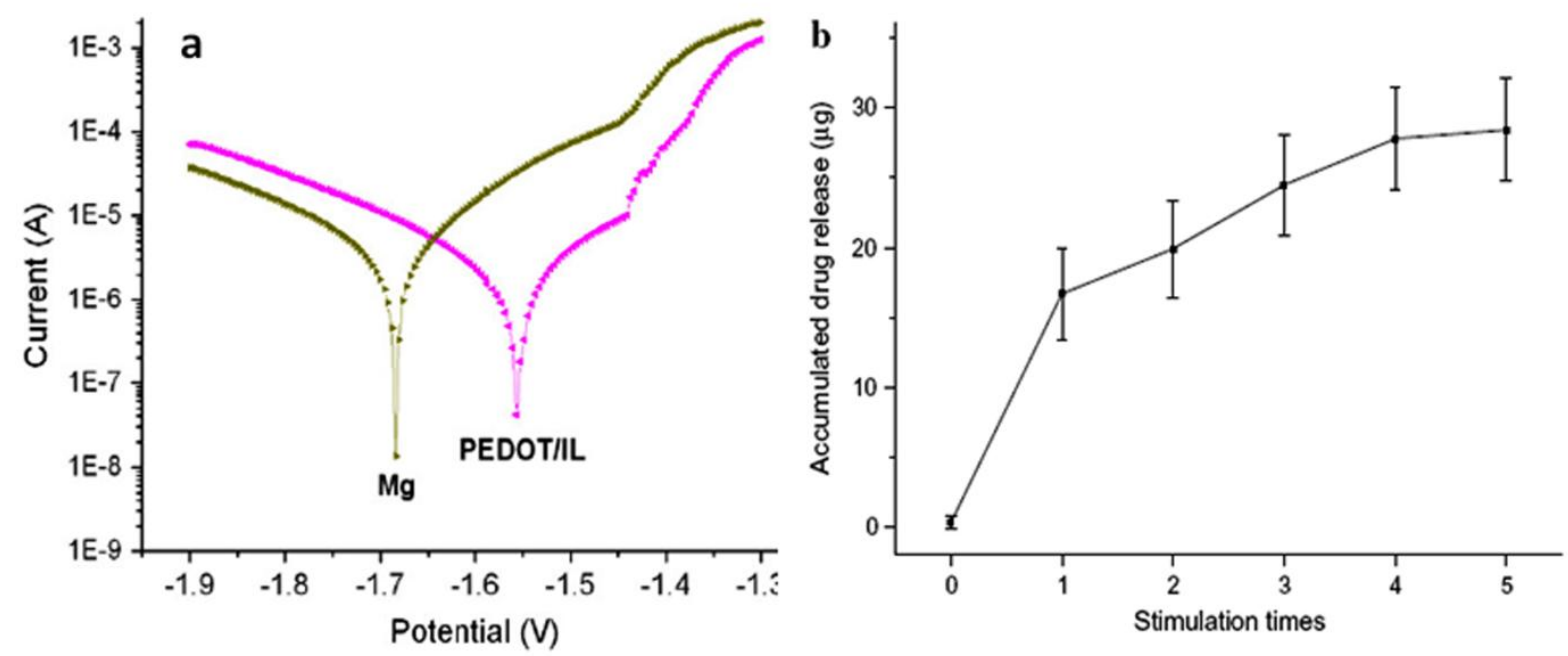
Table 1: Selected surgical metal implants/ material physical properties

\begin{tabular}{|c|c|c|c|c|c|c|c|}
\hline \multicolumn{2}{|c|}{ Tissue/Surgical Implants } & $\begin{array}{l}\text { Density } \\
\left(\mathrm{g} / \mathrm{cm}^{3}\right)\end{array}$ & $\begin{array}{l}\text { Yield } \\
\text { strength } \\
\text { (MPa) }\end{array}$ & $\begin{array}{l}\text { Tensile } \\
\text { strength } \\
\text { (MPa) }\end{array}$ & \begin{tabular}{|ll|}
\multicolumn{2}{|l|}{ Elongation } \\
to & break \\
$(\%)$ & \\
\end{tabular} & $\begin{array}{l}\text { Elastic } \\
\text { Modulus } \\
\text { (GPa) }\end{array}$ & Ref \\
\hline \multicolumn{2}{|l|}{ Bone } & $1.8-2.1$ & $104-121$ & $110-130$ & $0.7-3$ & $15-25$ & {$[117]$} \\
\hline \multicolumn{8}{|c|}{ Biodegradable metal alloys } \\
\hline \multirow{4}{*}{$\begin{array}{l}\mathrm{Mg} \text { and its } \\
\text { alloys }\end{array}$} & Pure $\mathrm{Mg}$ & $1.74-2.0$ & $65-100$ & $90-190$ & $2-10$ & $41-45$ & {$[1]$} \\
\hline & AZ31 & 1.78 & 185 & 263 & $15-23$ & 45 & \multirow{2}{*}[118]{} \\
\hline & AZ91 & 1.81 & 160 & 150 & 2.511 & 45 & \\
\hline & WE43 & 1.84 & 170 & 220 & $2-17$ & 44.2 & {$[120]$} \\
\hline \multirow{2}{*}{$\begin{array}{l}\mathrm{Fe} \text { and } \mathrm{Mn} \\
\text { alloys }\end{array}$} & Fe20Mn & 7.73 & 420 & 700 & 8 & 207 & \multirow[t]{2}{*}{ [121] } \\
\hline & Fe35Mn & --- & 230 & 430 & 32 & -- & \\
\hline $\begin{array}{|ll|}\mathrm{Zn} & \text { based } \\
\text { alloys } & \end{array}$ & $\mathrm{Zn}-\mathrm{Al}-\mathrm{Cu}$ & 5.79 & 171 & 210 & 1 & 90 & {$[122]$} \\
\hline \multicolumn{2}{|c|}{$\begin{array}{l}\text { Non-degradable } \\
\text { metal/composite implants }\end{array}$} & \multicolumn{5}{|c|}{+2} & \\
\hline \begin{tabular}{|l} 
Stainless \\
Steel
\end{tabular} & SS316L & & 190 & 490 & 40 & 200 & {$[123]$} \\
\hline \multirow{2}{*}{$\begin{array}{l}\text { Titanium } \\
\text { alloys }\end{array}$} & Ti-6Al-4V & 4.43 & 880 & 950 & 14 & 113.8 & \multirow{2}{*}[124]{} \\
\hline & Ti-6Al-7Nb & 4.52 & 800 & 900 & 10 & 105 & \\
\hline $\begin{array}{l}\text { Chromium- } \\
\text { cobalt alloys }\end{array}$ & CoCr20Ni15Mo7 & 7.8 & $240-450$ & $450-960$ & 50 & $195-230$ & {$[125]$} \\
\hline \multirow{2}{*}{ Bioceramics } & $\begin{array}{l}\text { Alumina } \\
\text { Ceramics }\end{array}$ & 4 & --- & $400-580$ & 0.12 & $260-410$ & \multirow[t]{2}{*}{ [126] } \\
\hline & $\begin{array}{l}\text { Synthetic } \\
\text { hydroxyapetite }\end{array}$ & 3.15 & |--- & $40-200$ & |---- & $70-120$ & \\
\hline \multicolumn{8}{|c|}{$\begin{array}{l}\text { Natural and synthetic } \\
\text { polyesters }\end{array}$} \\
\hline \multirow{4}{*}{$\begin{array}{l}\text { Natural and } \\
\text { synthetic } \\
\text { polyesters }\end{array}$} & $\begin{array}{l}\text { Collagen (Rat } \\
\text { tail) }\end{array}$ & --- & ---- & 2.6-605 & $7.40-26.74$ & $5-11.5$ & {$[127]$} \\
\hline & PLGA & $1.30-1.34$ & $3.8-26.6$ & 13.9-16.7 & 5.7 & 1.69 & {$[128]$} \\
\hline & PCL & 1.145 & $8.37-14.66$ & $68.45-102.7$ & $22.8-28.3$ & 281-686 & [129] \\
\hline & $\begin{array}{l}\text { PLA (67Kda) } \\
\text { PLA-59Kda } \\
\text { PLA-31Kda }\end{array}$ & $\begin{array}{l}1.8 \\
1.64 \\
1.04\end{array}$ & $\begin{array}{l}70 \\
68 \\
65\end{array}$ & $\begin{array}{l}59 \\
58 \\
55\end{array}$ & $\begin{array}{l}7.0 \\
5.0 \\
5.5\end{array}$ & $\begin{array}{l}3750 \\
3750 \\
3550\end{array}$ & [130] \\
\hline
\end{tabular}


Table 2: Corrosion studies of Mg and its alloys

\begin{tabular}{|c|c|c|c|c|c|c|c|c|c|c|c|}
\hline \multirow{2}{*}{$\begin{array}{l}\text { Mg } \\
\text { base } \\
\text { d } \\
\text { Meta } \\
\text { ls } \\
\end{array}$} & & \multicolumn{3}{|c|}{ In vitro degradation } & Ref & \multicolumn{5}{|c|}{ In vivo corrosion } & \multirow[t]{2}{*}{ Ref } \\
\hline & $\begin{array}{l}\text { Durat } \\
\text { ion } \\
\text { (days } \\
\text { ) }\end{array}$ & 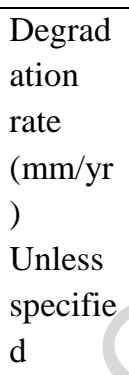 & $\begin{array}{l}\text { Corro } \\
\text { sive } \\
\text { Mediu } \\
\mathrm{m}\end{array}$ & $\begin{array}{l}\text { Method/ } \\
\text { Test }\end{array}$ & & $\begin{array}{l}\text { Durat } \\
\text { ion of } \\
\text { impla } \\
\mathrm{nt} \\
\text { (days } \\
\text { ) }\end{array}$ & 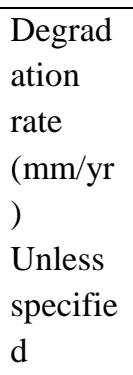 & $\begin{array}{l}\text { Method } \\
\text { /Test }\end{array}$ & $\begin{array}{l}\text { Implant } \\
\text { site }\end{array}$ & $\begin{array}{l}\text { Ani } \\
\text { mal }\end{array}$ & \\
\hline \multirow{10}{*}{$\begin{array}{l}\text { Pure } \\
\mathrm{Mg}\end{array}$} & \multirow{3}{*}{7} & 0.572 & EBSS & \multirow{9}{*}{$\begin{array}{l}\text { Weight } \\
\text { loss }\end{array}$} & \multirow{9}{*}{$\begin{array}{l}{[13} \\
1]\end{array}$} & 14 & 0.39 & \multirow{3}{*}{$\begin{array}{l}\text { Reductio } \\
\mathrm{n} \text { in } \\
\text { Volume }\end{array}$} & \multirow{3}{*}{ Ulnae } & \multirow{3}{*}{$\begin{array}{l}\text { Rab } \\
\text { bit }\end{array}$} & \multirow{3}{*}{$\begin{array}{l}{[13} \\
2]\end{array}$} \\
\hline & & 0.728 & MEM & & & 21 & 0.21 & & & & \\
\hline & & 2.185 & $\begin{array}{l}\text { MEM } \\
\mathrm{p}\end{array}$ & & & 56 & $30-40 \%$ & & & & \\
\hline & \multirow{3}{*}{14} & 0.468 & EBSS & & & 30 & $\begin{array}{ll}1.0 & \pm \\
0.3 & \end{array}$ & \multirow[t]{2}{*}{$\begin{array}{l}\text { Weight } \\
\text { loss }\end{array}$} & \multirow[t]{2}{*}{$\begin{array}{l}\text { muscle } \\
\text { fascia }\end{array}$} & \multirow[t]{2}{*}{ Rat } & \multirow{2}{*}{$\begin{array}{l}{[13} \\
3]\end{array}$} \\
\hline & & 0.676 & MEM & & & 60 & $0.7 \pm 0.3$ & & & & \\
\hline & & 1.483 & $\begin{array}{l}\text { MEM } \\
\mathrm{p}\end{array}$ & & & \multirow{4}{*}{ - } & \multirow{5}{*}{-} & \multirow{5}{*}{-} & \multirow[b]{5}{*}{-} & \multirow{5}{*}{-} & \multirow{5}{*}{-} \\
\hline & \multirow{3}{*}{21} & 0.382 & EBSS & & & & & & & & \\
\hline & & 0.659 & MEM & & & & & & & & \\
\hline & & 1.37 & $\begin{array}{l}\text { MEM } \\
\mathrm{p}\end{array}$ & & & & & & & & \\
\hline & $\begin{array}{c}4 \\
8 \\
20\end{array}$ & $\begin{array}{l}\text { Estimat } \\
\text { ed } \\
4.5 \\
2.5 \\
2.2 \\
\end{array}$ & SBF & $\begin{array}{l}\text { Weight } \\
\text { loss }\end{array}$ & $\begin{array}{l}{[13} \\
4]\end{array}$ & - & & & & & \\
\hline
\end{tabular}




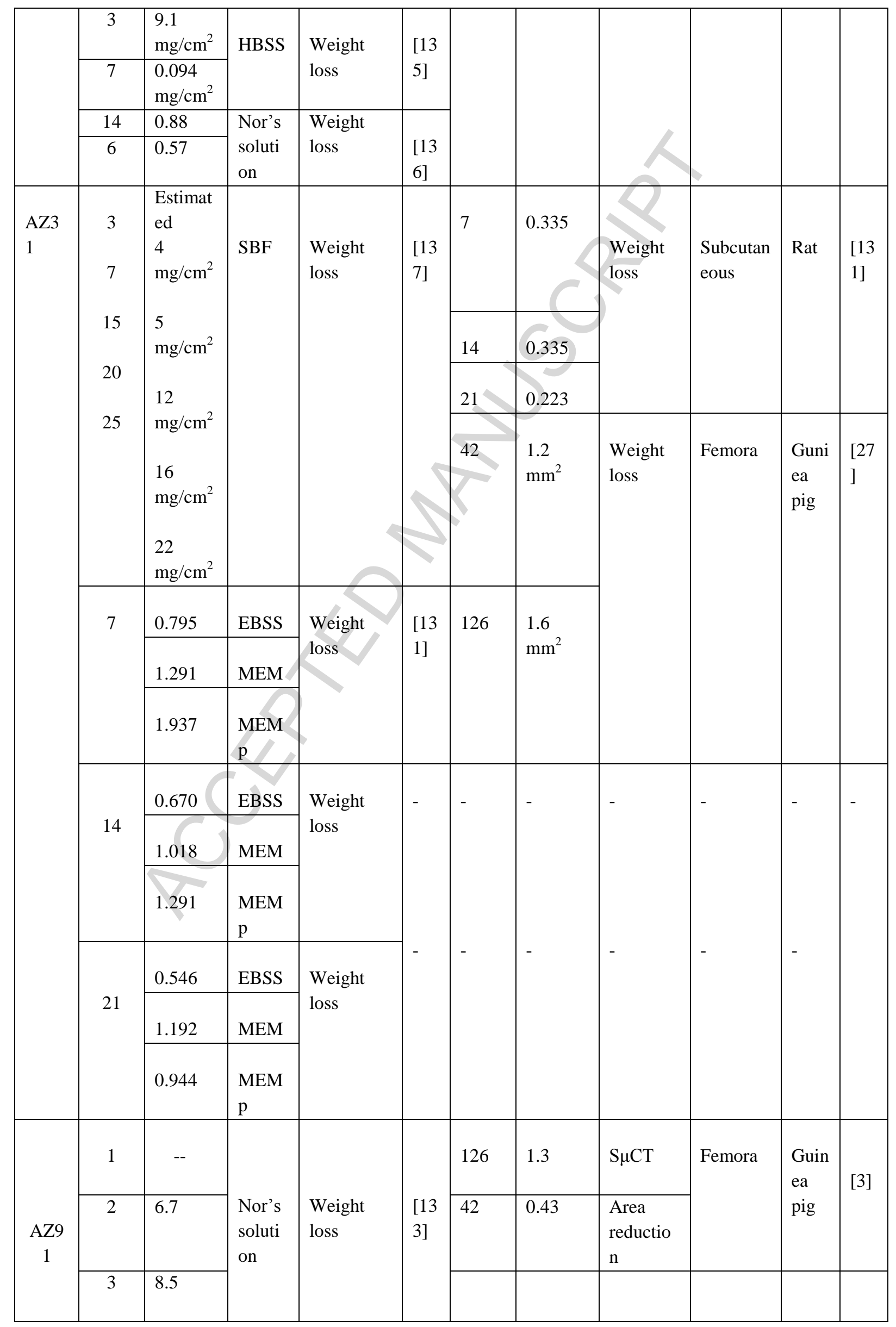




\begin{tabular}{|c|c|c|c|c|c|c|c|c|c|c|c|}
\hline & 4 & 3.5 & & & & \multirow{2}{*}{ - } & \multirow{2}{*}{ - } & \multirow[t]{2}{*}{-} & \multirow[t]{2}{*}{-} & \multirow[t]{2}{*}{-} & \\
\hline & 7 & 6 & $\begin{array}{l}\text { SBF2 } \\
7\end{array}$ & $\begin{array}{l}\text { Weight } \\
\text { loss }\end{array}$ & $\begin{array}{l}{[13} \\
6]\end{array}$ & & & & & & \\
\hline \multirow[t]{5}{*}{$\begin{array}{c}\text { AZ9 } \\
\text { 1D }\end{array}$} & \multirow[t]{4}{*}{$\begin{array}{c}10 \\
\text { days }\end{array}$} & -0.267 & $\begin{array}{l}\text { Ocean } \\
\text { water } \\
\text { Substi } \\
\text { tute }\end{array}$ & Immersion & $\begin{array}{l}{[13} \\
8]\end{array}$ & 14 & 1.17 & $\begin{array}{l}\text { Weight } \\
\text { loss }\end{array}$ & Subcutis & $\begin{array}{l}\text { Nud } \\
\mathrm{e} \\
\text { mice }\end{array}$ & $\begin{array}{l}{[13} \\
9]\end{array}$ \\
\hline & & 5.72 & \multirow[t]{3}{*}{$\begin{array}{l}1 \mathrm{M} \\
\mathrm{NaCl}\end{array}$} & \multirow[t]{3}{*}{$\begin{array}{l}\text { Electroche } \\
\text { mical }\end{array}$} & \multirow[t]{3}{*}{$\begin{array}{l}{[14} \\
0]\end{array}$} & 126 & $\begin{array}{l}0.00035 \\
16\end{array}$ & $\begin{array}{l}\text { Vol. } \\
\text { reductio } \\
\mathrm{n}\end{array}$ & Femur & $\begin{array}{l}\text { Guni } \\
\text { ea } \\
\text { pig } \\
\end{array}$ & $\begin{array}{l}{[13} \\
8]\end{array}$ \\
\hline & & 0.66 & & & & & & \multirow[b]{3}{*}{-} & \multirow[b]{3}{*}{-} & \multirow[b]{3}{*}{-} & \\
\hline & & 2.93 & & & & & & & & & \\
\hline & $\begin{array}{c}5 \\
7 \\
15 \\
20 \\
25\end{array}$ & $\begin{array}{l}\text { Estimat } \\
\text { ed } \\
4 \\
\mathrm{mg} / \mathrm{cm}^{2} \\
5 \\
\mathrm{mg} / \mathrm{cm}^{2} \\
6 \\
\mathrm{mg} / \mathrm{cm}^{2} \\
5 \\
\mathrm{mg} / \mathrm{cm}^{2} \\
4.2 \\
\mathrm{mg} / \mathrm{cm}^{2}\end{array}$ & SBF & $\begin{array}{l}\text { Weight } \\
\text { loss }\end{array}$ & $\begin{array}{l}{[13} \\
7]\end{array}$ & & & & & & \\
\hline \multirow{7}{*}{$\begin{array}{l}\text { LAE } \\
442\end{array}$} & \multirow[t]{2}{*}{10} & 6.9 & \multirow{2}{*}{$\begin{array}{l}\text { Ocean } \\
\text { water } \\
\text { Substi } \\
\text { tute }\end{array}$} & $\begin{array}{l}\text { Electroche } \\
\text { mical }\end{array}$ & $\begin{array}{l}{[13} \\
8]\end{array}$ & 14 & 0.0134 & $\mu \mathrm{CT}$ & $\begin{array}{l}\text { Medullar } \\
\text { y cavity }\end{array}$ & $\begin{array}{l}\text { Rab } \\
\text { bit }\end{array}$ & $\begin{array}{l}{[14} \\
1]\end{array}$ \\
\hline & & 5.535 & & $\begin{array}{l}\text { Weight } \\
\text { loss }\end{array}$ & $\begin{array}{l}{[14} \\
2]\end{array}$ & 126 & $\begin{array}{l}1.205 \\
\times 10^{-4}\end{array}$ & $\mathrm{~S} \mu \mathrm{CT}$ & Femora & $\begin{array}{l}\text { Guin } \\
\text { ea } \\
\text { pig }\end{array}$ & $\begin{array}{l}{[13} \\
8]\end{array}$ \\
\hline & \multirow[t]{5}{*}{ - } & & \multirow[t]{5}{*}{ - } & \multirow[t]{5}{*}{ - } & \multirow[t]{5}{*}{-} & 365 & $40 \%$ & $\begin{array}{l}\text { \%vol. } \\
\text { reductio } \\
\mathrm{n}\end{array}$ & Tibia & $\begin{array}{l}\text { Rab } \\
\text { bit }\end{array}$ & $\begin{array}{l}\text { [14 } \\
3]\end{array}$ \\
\hline & & & & & & 42 & $\begin{array}{l}1.6 \\
\mathrm{~mm}^{2}\end{array}$ & \multirow{2}{*}{$\begin{array}{l}\text { Weight } \\
\text { loss }\end{array}$} & \multirow[t]{2}{*}{ Femora } & \multirow{2}{*}{$\begin{array}{l}\text { Guin } \\
\text { ea } \\
\text { pig }\end{array}$} & \multirow{2}{*}{$\begin{array}{l}{[27} \\
]\end{array}$} \\
\hline & & & & & & 126 & $\begin{array}{l}1.45 \\
\mathrm{~mm}^{2}\end{array}$ & & & & \\
\hline & & & & & & 60 & $\begin{array}{l}0.02 \\
\mathrm{~cm}^{3} \\
(\text { decrea } \\
\text { sed) }\end{array}$ & \multirow[t]{2}{*}{$\begin{array}{l}\text { Volume } \\
\text { determin } \\
\text { ation }\end{array}$} & \multirow[t]{2}{*}{ Tibiae } & \multirow[t]{2}{*}{$\begin{array}{l}\text { Rab } \\
\text { bit }\end{array}$} & \multirow[t]{2}{*}{$\begin{array}{l}{[14} \\
4]\end{array}$} \\
\hline & & & & & & 120 & $\begin{array}{l}0.03 \\
\mathrm{~cm}^{3} \\
\text { decreas } \\
\text { ed }\end{array}$ & & & & \\
\hline \multirow{2}{*}{$\begin{array}{l}\mathrm{Mg}- \\
0.8 \mathrm{C} \\
\mathrm{a}\end{array}$} & \multirow[t]{2}{*}{7} & 0.573 & EBSS & \multirow[b]{2}{*}{$\begin{array}{l}\text { Weight } \\
\text { loss }\end{array}$} & \multirow[b]{2}{*}{$\begin{array}{l}{[13} \\
1]\end{array}$} & & & & & & \\
\hline & & 0.937 & MEM & & & & & & & & \\
\hline
\end{tabular}




\begin{tabular}{|c|c|c|c|c|c|c|c|c|c|c|c|}
\hline & & 2.812 & $\begin{array}{l}\text { MEM } \\
\mathrm{p}\end{array}$ & & & & & & & & \\
\hline & 14 & 0.521 & EBSS & & & & & & & & \\
\hline & & 0.833 & MEM & $\begin{array}{l}\text { Weight } \\
\text { loss }\end{array}$ & $\begin{array}{l}{[13} \\
1]\end{array}$ & 365 & $62 \%$ & $\begin{array}{l}\% \text { vol. of } \\
\text { Reductio } \\
\mathrm{n}\end{array}$ & Tibia & $\begin{array}{l}\text { Rab } \\
\text { bit }\end{array}$ & $\begin{array}{l}{[14} \\
3]\end{array}$ \\
\hline & & 1.901 & $\begin{array}{l}\text { MEM } \\
p\end{array}$ & & & 7 & 0.312 & \multirow{3}{*}{$\begin{array}{l}\text { Weight } \\
\text { loss }\end{array}$} & \multirow{3}{*}{$\begin{array}{l}\text { Subcutan } \\
\text { eous }\end{array}$} & \multirow[t]{3}{*}{ Rat } & \multirow[t]{3}{*}{$\begin{array}{l}{[13} \\
1]\end{array}$} \\
\hline & \multirow[t]{3}{*}{21} & 0.382 & EBSS & \multirow{3}{*}{$\begin{array}{l}\text { Weight } \\
\text { loss }\end{array}$} & & 14 & 0.430 & & & & \\
\hline & & 0.764 & MEM & & & 21 & 0.351 & & & & \\
\hline & & 1.545 & $\begin{array}{l}\text { MEM } \\
\mathrm{p}\end{array}$ & & & $\begin{array}{l}60 \\
120\end{array}$ & $\begin{array}{l}0.02 \\
\mathrm{~cm}^{3} \\
(\text { Decrea } \\
\text { sed) } \\
0.05 \\
\mathrm{~cm}^{3} \\
(\text { Decrea } \\
\text { sed) }\end{array}$ & $\begin{array}{l}\text { Volume } \\
\text { determin } \\
\text { ation }\end{array}$ & Tibiae & $\begin{array}{l}\text { Rab } \\
\text { bit }\end{array}$ & $\begin{array}{l}{[14} \\
4]\end{array}$ \\
\hline \multirow{5}{*}{$\begin{array}{l}\text { WE4 } \\
3\end{array}$} & 0 & 0.79 & $\begin{array}{l}0.01 \\
\mathrm{M} \\
\mathrm{NaCl}\end{array}$ & \multirow[t]{5}{*}{$\begin{array}{l}\text { Electroch- } \\
\text { emical }\end{array}$} & \multirow[t]{5}{*}{$\begin{array}{l}{[14} \\
5]\end{array}$} & 42 & $\begin{array}{l}1.2 \\
\mathrm{~mm}^{2}\end{array}$ & \multirow[t]{2}{*}{$\begin{array}{l}\text { Weight } \\
\text { loss }\end{array}$} & \multirow[t]{2}{*}{ Femora } & \multirow{2}{*}{$\begin{array}{l}\text { Guin } \\
\text { ea } \\
\text { pig }\end{array}$} & \multirow[t]{2}{*}{$\begin{array}{l}{[27} \\
]\end{array}$} \\
\hline & - & 2.91 & $\begin{array}{l}0.2 \mathrm{M} \\
\mathrm{NaCl}\end{array}$ & & & 126 & $\begin{array}{l}1.0 \\
\mathrm{~mm}^{2}\end{array}$ & & & & \\
\hline & - & & $\begin{array}{l}0.6 \mathrm{M} \\
\mathrm{NaCl}\end{array}$ & & & 60 & $\begin{array}{l}0.01 \\
\mathrm{~cm}^{3} \\
\text { (Decrea } \\
\text { sed) }\end{array}$ & $\begin{array}{l}\text { Volume } \\
\text { determin } \\
\text { ation }\end{array}$ & Tibiae & $\begin{array}{l}\text { Rab } \\
\text { bit }\end{array}$ & $\begin{array}{l}{[14} \\
4]\end{array}$ \\
\hline & - & 5.84 & $\begin{array}{l}1.0 \mathrm{M} \\
\mathrm{NaCl}\end{array}$ & & & 120 & $\begin{array}{l}0.06 \\
\mathrm{~cm}^{3}\end{array}$ & & & & \\
\hline & - & 6.97 & $\begin{array}{l}2.0 \mathrm{M} \\
\mathrm{NaCl}\end{array}$ & & & & $\begin{array}{l}\text { (Decrea } \\
\text { sed) }\end{array}$ & & & & \\
\hline
\end{tabular}


Table 3: Elemental compositions (\% wt.) of selected Mg alloys

\begin{tabular}{|l|l|l|l|l|l|l|l|l|l|l|l|}
\hline $\begin{array}{l}\text { Magnesium } \\
\text { alloys }\end{array}$ & Ca & Al & Mn & $\mathbf{Z n}$ & $\mathbf{L i}$ & $\mathbf{N d}$ & $\mathbf{Z r}$ & $\mathbf{Y}$ & $\mathbf{M g}$ & $\begin{array}{l}\text { Other trace } \\
\text { elements } \\
\text { wt. })\end{array}$ \\
\hline AZ31 & - & 2.4 & 0.4 & 0.8 & - & - & - & - & 96.7 & $\begin{array}{l}\text { Cu-0.008,Fe- } \\
0.003, \mathrm{Be}-0.005\end{array}$ & $\begin{array}{l}{[27]} \\
{[33]} \\
{[146]}\end{array}$ \\
\hline AZ91 & - & 9.0 & 0.13 & 0.5 & - & - & - & - & 90.37 & $\begin{array}{l}\text { Cu-0.003,Fe- } \\
0.014, \mathrm{Be}-0.002\end{array}$ & \\
\hline WE43 & - & - & - & - & - & $2.4-3.2$ & 0.4 & $3.7-4.3$ & $92.1-93.5$ & & {$[146]$} \\
\hline LAE442 & - & 2.2 & 0.2 & 0.2 & 3.9 & 2.0 & - & - & 91.5 & & {$[27]$} \\
\hline AM60 & - & 6.0 & 0.13 & 0.1 & - & - & - & - & 93.77 & $\begin{array}{l}\text { Cu-0.008,Fe- } \\
0.004, \text { Be-0.005 }\end{array}$ & {$[146]$} \\
\hline MgCa0.8 & 0.8 & - & - & - & - & - & - & - & 99.2 & & {$[146]$} \\
\hline Mg6Zn & 6 & - & - & - & - & - & - & - & 94 & & {$[146]$} \\
\hline
\end{tabular}


Table 4: Pathophysiology of alloying elements in Mg alloy (Ref: [15], [139], [140], [54], [55]).

\begin{tabular}{|c|c|c|c|c|c|}
\hline Elements & $\begin{array}{l}\text { Effect on the alloying } \\
\text { element }\end{array}$ & \begin{tabular}{|l|} 
Normal \\
amount \\
present in \\
human \\
body
\end{tabular} & Pathophysiology & Toxicology & $\begin{array}{l}\text { TD50 of } \\
\text { Bone related cells } \\
(\mathrm{mol} / \mathrm{L})\end{array}$ \\
\hline $\mathrm{Mg}$ & ----- & $25 \mathrm{~g}$ & $\begin{array}{l}\text { Normal blood serum level 0.73- } \\
1.06 \mathrm{mmol} / \mathrm{L} \\
\text { Required for ATP synthesis. } \\
\text { activator of many enzymes; co- } \\
\text { regulator of protein synthesis, } \\
\text { stabiliser of DNA and RNA }\end{array}$ & $\begin{array}{l}\text { Disorder in magnesium } \\
\text { homeostasis leads to } \\
\text { nausea, renal failure, } \\
\text { impaired breathing. }\end{array}$ & $73 \times 10^{-3}$ \\
\hline $\mathrm{Ca}$ & $\begin{array}{l}\text { Induce } \\
\text { resistance in } \quad \mathrm{Mg}-\mathrm{Ca} \\
\text { alloys }\end{array}$ & $1100 \mathrm{~g}$ & $\begin{array}{l}\text { Normal serum level 0.919-0.993 } \\
\mathrm{mg} / \mathrm{L} \\
\text { Control muscle contraction, } \\
\text { maintain homeostasis of bone, } \\
\text { hormones and neurotransmitter } \\
\text { release regulator }\end{array}$ & $\begin{array}{l}\text { Dysregulation of calcium } \\
\text { levels in the body leads } \\
\text { to kidney stones, } \\
\text { Hypoparathyrodism, } \\
\text { cardiac unrest }\end{array}$ & $>50 \times 10^{-3}$ \\
\hline $\mathrm{Al}$ & $\begin{array}{l}\text { Acts as passivating } \\
\text { element and improve } \\
\text { corrosion resistance }\end{array}$ & $<300 \mathrm{mg}$ & $\begin{array}{l}\text { Normal blood serum level 2.1-4.8 } \\
\mu \mathrm{g} / \mathrm{L} \text {. }\end{array}$ & $\begin{array}{l}\text { Excess amounts leads to } \\
\text { neurotoxicity, } \\
\text { Alzheimer's, } \\
\text { accumulation in bone } \\
\text { leads to decreases } \\
\text { osteoclast viability. }\end{array}$ & $>5 \times 10^{-3}$ \\
\hline $\mathrm{Zn}$ & $\begin{array}{l}\text { Improves compatibility } \\
\text { with bone by modifying } \\
\text { yield stress and Elastic } \\
\text { modulus. } \\
\begin{array}{lll}\text { Decreases } & \mathrm{H}_{2} & \text { gas } \\
\text { release } & & \end{array}\end{array}$ & 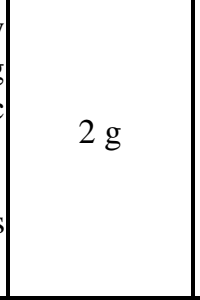 & $\begin{array}{l}\text { Normal blood serum level 12.4- } \\
17.4 \mu \mathrm{mol} / \mathrm{L} \\
\text { Essential elements for immune } \\
\text { system. }\end{array}$ & $\begin{array}{l}\text { Excessive amounts leads } \\
\text { neurotoxic, cramps and } \\
\text { diarrhoea }\end{array}$ & $9.28 \times 10^{-5}$ \\
\hline
\end{tabular}




\begin{tabular}{|c|c|c|c|c|c|}
\hline $\mathrm{Mn}$ & $\begin{array}{l}\text { Improve } \quad \text { corrosion } \\
\text { resistance }\end{array}$ & $12 \mathrm{mg}$ & $\begin{array}{l}\text { Normal blood serum level }<0.8 \\
\mu \mathrm{g} / \mathrm{L} \\
\text { Activator of various enzymes }\end{array}$ & $\begin{array}{l}\text { Excessive amounts cause } \\
\text { psychiatric and motor } \\
\text { disturbances }\end{array}$ & $4.59 \times 10^{-5}$ \\
\hline $\mathrm{Li}$ & $\begin{array}{l}\text { Improve } \\
\text { resistance }\end{array}$ & -- & $\begin{array}{l}\text { Normal blood serum level } 2-4 \\
\mathrm{ng} / \mathrm{g} \\
\text { Used in the treatment of } \\
\text { depressive disorders }\end{array}$ & $\begin{array}{l}\text { Overdose causes } \\
\text { impaired kidney function } \\
\text { and respiratory disorders }\end{array}$ & $1.32 \times 10^{-2}$ \\
\hline $\mathrm{Cu}$ & $\begin{array}{l}\text { Increase strength of } \\
\text { Magnesium cast }\end{array}$ & -- & $\begin{array}{l}\text { normal blood serum level } 74-131 \\
\mu \mathrm{mol} / \mathrm{L} \\
\text { Involved in respiratory chain and } \\
\text { enzyme co-factors }\end{array}$ & $\begin{array}{l}\text { Causes hypotension, } \\
\text { jaundice, melena etc. }\end{array}$ & $4.15 \times 10^{-5}$ \\
\hline $\mathrm{Y}$ & $\begin{array}{l}\text { Improve ductility and } \\
\text { corrosion resistance }\end{array}$ & -- & Blood serum level $<47 \mu \mathrm{g}$ & $\begin{array}{l}\text { Higher concentration } \\
\text { accumulate in liver and } \\
\text { gall bladder }\end{array}$ & $2.54 \times 10^{-4}$ \\
\hline $\mathrm{Zr}$ & $\begin{array}{l}\text { Improver tensile } \\
\text { strength, ductility and } \\
\text { corrosion resitance }\end{array}$ & $<250 \mathrm{mg}$ & Low sy & $\begin{array}{l}\text { Deposited on bone and } \\
\text { cationic form cause } \\
\text { deposition on bone }\end{array}$ & $1.64 \times 10^{-3}$ \\
\hline
\end{tabular}


Table 5: Corrosion studies of polymers coated on Magnesium alloy

\begin{tabular}{|c|c|c|c|c|c|c|c|}
\hline $\begin{array}{l}\text { Polymer } \\
\text { s/ } \\
\text { Composi } \\
\text { tes }\end{array}$ & Deoraded nroducts & Magnesium alloy & $\begin{array}{c}\mathbf{I}_{\text {corr }} \\
(\boldsymbol{\mu} \mathrm{A} / \mathbf{c m}\end{array}$ & $\mathbf{E}_{\text {cor }}$ & Corrosi & Coating & Ref. \\
\hline $\begin{array}{l}\text { Syntheti } \\
\text { c } \\
\text { polyeste } \\
\text { rs }\end{array}$ & & & $\begin{array}{c}\text {,unless } \\
\text { Indicat } \\
\text { ed) }\end{array}$ & (V) & $\underset{\mathbf{m}}{\text { Mediu }}$ & & \\
\hline \multirow{3}{*}{$\begin{array}{l}\text { Poly } \\
\text { Lactic } \\
\text { acid }\end{array}$} & \multirow{3}{*}{ Lactic acid } & PLA-AZ31 & & $\begin{array}{c}1.5 \\
7\end{array}$ & SBF & \multirow{3}{*}{$\begin{array}{l}\text { Dip } \\
\text { coating }\end{array}$} & [85] \\
\hline & & PLA-MAO-AZ31 & 1.83 & $\begin{array}{c}- \\
1.5 \\
0\end{array}$ & & & \\
\hline & & $\begin{array}{l}\mathrm{Mg}-1.21 \mathrm{Li}- \\
1.12 \mathrm{Ca}-1.0 \mathrm{Y}\end{array}$ & 1.7 & -- & $\begin{array}{l}\text { Hanks' } \\
\text { buffer }\end{array}$ & & $\begin{array}{c}{[147} \\
]\end{array}$ \\
\hline \multirow{8}{*}{ PLGA } & \multirow{8}{*}{$\begin{array}{c}\text { d.l-lactic acid } \\
\text { and glycolic acid }\end{array}$} & Mg Ammlite & 3 & $\begin{array}{c}- \\
1.5 \\
2\end{array}$ & $\begin{array}{l}0.1 \mathrm{M} \\
\mathrm{NaCl}\end{array}$ & $\begin{array}{c}\text { Electrospra } \\
\mathrm{y}\end{array}$ & [94] \\
\hline & & $\mathrm{Mg}-6 \mathrm{Zn}$ & 0.085 & $\begin{array}{c}- \\
1.4 \\
4\end{array}$ & $\begin{array}{l}0.9 \% \\
\mathrm{NaCl}\end{array}$ & $\begin{array}{c}\text { Dip } \\
\text { coating }\end{array}$ & [95] \\
\hline & & AZ31-PLGA $10 \%$ & 5.20 & $\begin{array}{c}- \\
1.4 \\
69\end{array}$ & \multirow[t]{4}{*}{ DMEM } & \multirow{4}{*}{$\begin{array}{l}\text { Dip } \\
\text { coating }\end{array}$} & \multirow[t]{4}{*}{ [93] } \\
\hline & & AZ31-PLGA $20 \%$ & 6.05 & $\begin{array}{c}- \\
1.4 \\
5\end{array}$ & & & \\
\hline & & Mg4Y-PLGA $10 \%$ & 8.09 & $\begin{array}{c}- \\
1.4 \\
85\end{array}$ & & & \\
\hline & & Mg4Y-PLGA $20 \%$ & 6.85 & $\begin{array}{c}- \\
1.4 \\
69\end{array}$ & & & \\
\hline & & PLGA 50:50 & 1.12 & $\begin{array}{c}- \\
1.5 \\
2\end{array}$ & \multirow[t]{2}{*}{ DMEM } & \multirow[t]{2}{*}{$\begin{array}{l}\text { Dip } \\
\text { coating }\end{array}$} & \multirow[t]{2}{*}{$\begin{array}{c}{[148} \\
]\end{array}$} \\
\hline & & PLGA 75:25 & 1.56 & $\begin{array}{c}- \\
1.4 \\
4\end{array}$ & & & \\
\hline $\begin{array}{l}\text { Poly(cap } \\
\text { ro- }\end{array}$ & Caproic acid & $\begin{array}{c}\text { MAO-4PCL duplex } \\
\text { coated }\end{array}$ & 0.81 & $\begin{array}{r}-1 \\
72\end{array}$ & $\begin{array}{l}\text { Hanks' } \\
\text { buffer }\end{array}$ & & [97] \\
\hline
\end{tabular}




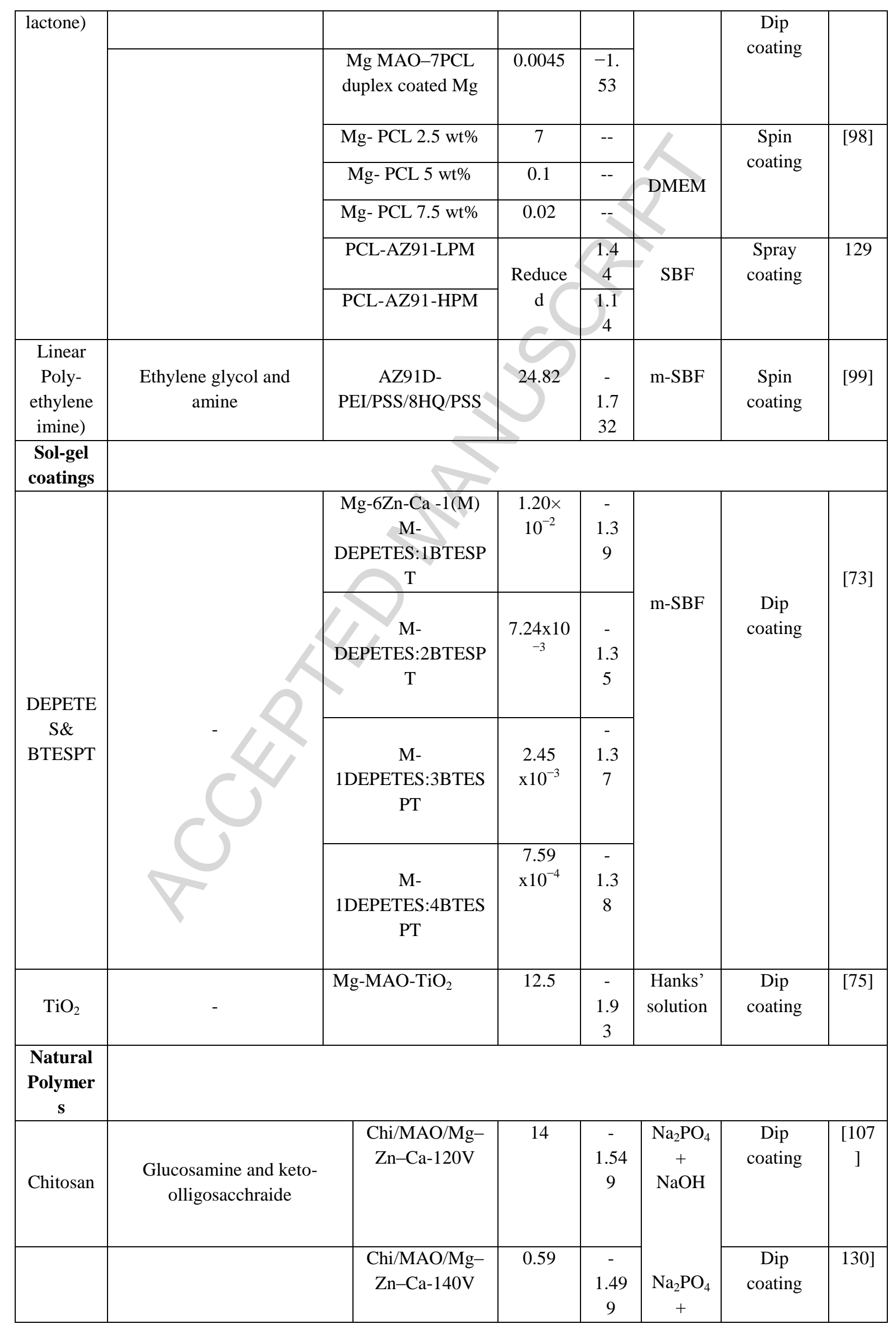




\begin{tabular}{|c|c|c|c|c|c|c|c|}
\hline & & & & & $\mathrm{NaOH}$ & & \\
\hline & & $\begin{array}{l}\text { MAO-WE43- } \\
\text { chitosan- } \\
\text { polystyrene- } \\
\text { LBL }\end{array}$ & 2.796 & $\begin{array}{c}- \\
1.29 \\
5\end{array}$ & SBF & $\begin{array}{c}\text { Spin } \\
\text { coating }\end{array}$ & $\begin{array}{c}{[101} \\
]\end{array}$ \\
\hline & & $\begin{array}{l}\text { AZ91E-5\% } \\
\text { chitosan }\end{array}$ & 0.322 & $\begin{array}{c}- \\
1.56 \\
2\end{array}$ & \multirow{3}{*}{$\begin{array}{l}\text { Synthet } \\
\text { ic } \\
\text { Sweat }\end{array}$} & \multirow[t]{3}{*}{$\begin{array}{l}\text { Dip } \\
\text { coating }\end{array}$} & \multirow[t]{3}{*}{$\begin{array}{c}{[100} \\
]\end{array}$} \\
\hline & & $\begin{array}{l}\text { AZ91E-10\% } \\
\text { chitosan }\end{array}$ & 0.136 & 1.53 & & & \\
\hline & & $\begin{array}{l}\text { AZ91E-15\% } \\
\text { chitosan }\end{array}$ & 0.116 & $\begin{array}{c}1.48 \\
3\end{array}$ & & & \\
\hline \multicolumn{8}{|l|}{$\begin{array}{l}\text { Natural } \\
\text { polymer } \\
\text { Composi } \\
\text { tes }\end{array}$} \\
\hline \multirow[t]{3}{*}{$\begin{array}{l}\text { HA- } \\
\text { chitosan }\end{array}$} & $\begin{array}{c}\text { CaPO4 and } \\
\text { Glucosamine and keto } \\
\text { olligosacchraide }\end{array}$ & $\begin{array}{c}\text { HA-5 wt.\% } \\
\text { chitosan-AZ31 }\end{array}$ & 15.1 & $\begin{array}{c}- \\
1.60 \\
1\end{array}$ & \multirow[t]{3}{*}{ SBF } & \multirow{3}{*}{$\begin{array}{l}\text { Spray } \\
\text { coating }\end{array}$} & \multirow[t]{3}{*}{$\begin{array}{c}{[13} \\
1]\end{array}$} \\
\hline & & $\begin{array}{l}\text { HA-10 wt.\% } \\
\text { chitosan- } \\
\text { AZ31 }\end{array}$ & 31.4 & $\begin{array}{c}- \\
1.58 \\
1\end{array}$ & & & \\
\hline & & $\begin{array}{c}\text { HA-20 wt.\% } \\
\text { chitosan-AZ31 }\end{array}$ & 50.9 & $\begin{array}{c}- \\
1.58 \\
6\end{array}$ & & & \\
\hline $\begin{array}{c}\text { Stearic } \\
\text { acid } \\
\text { and } \\
\text { magnesi } \\
\text { um state }\end{array}$ & Stearic acid & AZ31 & 4 & -1.71 & $\begin{array}{l}\text { Hanks' } \\
\text { solutio } \\
\quad \mathrm{n}\end{array}$ & Dip coating & $\begin{array}{c}{[14} \\
9]\end{array}$ \\
\hline \multirow[b]{2}{*}{ Collagen } & \multirow[b]{2}{*}{$\begin{array}{c}\text { Hydroxylysine/proline/hydro } \\
\text { xyproline }\end{array}$} & \multirow[b]{2}{*}{ AZ31 } & 0.00223 & -1.48 & SBF & $\begin{array}{l}\text { Electrospin } \\
\text { ning }\end{array}$ & \multirow{2}{*}{$\begin{array}{c}{[15} \\
0]\end{array}$} \\
\hline & & & 3.741 & $\begin{array}{l}- \\
1.46 \\
0\end{array}$ & SBF & Dip coating & \\
\hline
\end{tabular}




\section{Highlights:}

- The Mg based alloys are promising candidates for orthopaedic applications.

- The rapid corrosion of $\mathrm{Mg}$ can affect human cells, causes infection and implant failure.

- The various physiological factors and Mg alloying elements affecting the corrosion and mechanical properties of implants.

- The polymeric deposit coatings enhance the corrosion resistance and biocompatibility. 